Portland State University

PDXScholar

Winter 2-9-2015

\title{
Die unbewältigte Vergangenheit: the Third Generation and the Holocaust in Recent Literature and Film
}

Dana Lynne Capage

Portland State University

Follow this and additional works at: https://pdxscholar.library.pdx.edu/open_access_etds Let us know how access to this document benefits you.

\section{Recommended Citation}

Capage, Dana Lynne, "Die unbewältigte Vergangenheit: the Third Generation and the Holocaust in Recent Literature and Film" (2015). Dissertations and Theses. Paper 2232.

https://doi.org/10.15760/etd.2229

This Thesis is brought to you for free and open access. It has been accepted for inclusion in Dissertations and Theses by an authorized administrator of PDXScholar. Please contact us if we can make this document more accessible: pdxscholar@pdx.edu. 
Die unbewältigte Vergangenheit:

the Third Generation and the Holocaust in Recent Literature and Film

by

Dana Lynne Capage

A thesis submitted in partial fulfillment of the requirements for the degree of

\section{Master of Arts}

in

German

Thesis Committee:

Timm Menke, Chair

Steven Nyole Fuller

Kathleen A. Godfrey

Portland State University

2015 


\begin{abstract}
Processing the Holocaust and its disruption to society has emerged as a significant preoccupation, both privately and publicly, since the war ended almost seventy years ago. By taking up the topic, contemporary artists, often called the "third generation," die Enkel or die Dritten in German, argue that grappling with the past is a process that cannot yet be laid to rest. The cultural production of some of these artists is the focus of this study.

Some, like German literary scholar Ernestine Schlant, have argued that past efforts to process history have been lacking. Her review of West German, post-war literature, The Language of Silence, is surveyed for the purpose of understanding how previous generations tackled the topic and how success in confronting the issues could be measured.
\end{abstract}

Four artists represent their views on the burden of history in works produced in the first decade of the new century. In Schweigen die Täter, reden die Enkel, Claudia Brunner describes her efforts to recognize and deal with the feelings of Phantomschmerzen as a result of being a descendent of a Nazi perpetrator. Himmelskörper, by Tanja Dückers, portrays a new mother trying to discover the secrets her grandmother harbors; Uwe von Seltmann wrestles with the legacy of unpunished crimes in Karlebachs Vermächtnis; and, denial takes center stage as Jens Schanze documents his family's attempts to end the silence about a Nazi grandfather in the film Winterkinder.

Lest it be thought contemporary artists saw no importance in the legacy of the Holocaust or were not inclined to tackle political issues, this study contends that modern artists are not only capable of confronting the past, but that they find the confrontation 
still necessary. Given their temporal distance to the era, they have an advantage over previous generations to approach the issues with more objectivity and composure. They do this work in service to others who seek to understand the pain and guilt they feel; to those who sense secrets in their family's history that remain buried and harmful; to those who were wronged; to those who suffer from long-suppressed conflict; and, to those who care deeply, also from afar, that German society successfully digest, but not forget, the history. 


\section{Table of Contents}

Abstract

Chapter 1 - Introduction 1

Chapter 2 - Cultural Production in Continuity 5

Chapter 3 - Die Dritten in Literature and Film

Schweigen die Täter, reden die Enkel 20

$\begin{array}{ll}\text { Himmelskörper } & 32\end{array}$

$\begin{array}{ll}\text { Karlebachs Vermächtnis } & 65\end{array}$

$\begin{array}{ll}\text { Winterkinder } & 79\end{array}$

$\begin{array}{ll}\text { Conclusion } & 95\end{array}$

$\begin{array}{ll}\text { Sources Cited } & 102\end{array}$ 
Chapter 1

Introduction

What to do with the reality of the Holocaust is a question that has not conveniently gone away with time. Seventy years of post-war continuity have provided countless opportunities to get at various aspects of the human behavior responsible for what is arguably one of the worst periods of modern human history; cultural producers have obliged. The questions are posed: are we done? Has every aspect been examined? Do we know everything we need to know? What is the goal of our pursuit of knowledge of this era in history? What responsibility does the current generation have to those who have come before, not insignificantly to those who were denied the right to exist because of the actions of others? Haben wir die Vergangenheit bewältigt? Have we mastered the past? A current generation of authors is taking up these questions. They are demonstrating that, from their perspective anyway, we are not, indeed cannot, be done. Naturally, the current generation of authors grapples with many topics. These authors, born at the end of the Sixties or the beginning of the Seventies, are the grandchildren of the war generation. They come in a long line of authors since the end of the war that has, to varying degrees and with varying success, taken up the topic of the Holocaust. As Anke Biendarra argued in her study, Germans Going Global, it "has become acceptable again" for contemporary German authors to use political and societal situations as backdrop for their cultural production (5). While perhaps not viewing themselves as "public intellectuals" or thinking their work should be seen as an invitation to political action, as others such as Grass or Walser in their time were content to be, Biendarra states that modern authors are interested in tackling topics that these authors 
had tackled (5). According to Biendarra, the German literature taking on these topics broadly falls into two groups: one is literature that deals with the effects of globalization on German society; the second is literature that looks into how to deal with the German past. This literature has been named "realistic memory literature" or "memory contests" (5).

Viewing literature as a reflection of society, of what is going on and what is being thought about by individuals in society at large is to adopt the view of the tradition of German Studies scholars all around. Reading "texts as interventions in the social process" (Biendarra 11) is an accepted practice. Authors reflect and create culture simultaneously.

The fact that contemporary German authors feel that the past is still relevant enough to write about clearly indicates that they feel their society has not "mastered" the past, as was inherently implied as possible in the ever-repeated term Vergangenheitsbewältigung. Additionally, they are rejecting the idea of a "zero hour," the Stunde Null, a loaded term that has gathered meaning over the decades. While used to refer to the supposed break that happened at the end of the war, a break in society as well as in literature, the concept was helpful to those who wanted to put distance between themselves and a past that was too awful to deal with (Brockmann 25). Modern authors, rather than viewing 1945 as a breaking point, only see continuity. Knowing about the past is central to a modern German identity, these authors are saying. Culture critics support this view. Ernestine Schlant, German literary scholar, claims in her book, The Language of Silence: West German Literature and the Holocaust, that the Holocaust has simply "become part of German self-understanding" (2). To not deal with the topic would be to deny a part of one's identity. In addition, this generation is also searching for answers, for 
an understanding. At various points in history, it has been thought that an end point for the examination would come about. Not only would investigations no longer be done, society and individuals could move on without the burden of the past. But building an identity in the face of the atrocities one's society is responsible for - and is continually reminded of - is still required, as difficult as it may be to soberly understand the facts.

To put a framework around the topics modern authors are paying attention to, it is instructive to view their production in the continuity they are producing it in. The authors, of course, do not write in a vacuum. One can argue that the Germans are dealing with their history on a very public stage, and opinions about their success or failure abound. Critics offer ideas about what is important, but the authors reveal their grappling with the issues, informed by the struggles they have faced in the process. Each generation of authors has its trademarks. The immediate post-war authors and the second generation deal with the topic differently than the third generation. Given the simple passage of time and the distance thereby achieved, the third generation is uniquely positioned to investigate the burden of the past while living in a society that is arguably a strong and liberal democracy. Preserving, and bettering, the society that grew up from the rubble of fascism requires the investigation the authors are undertaking.

In their mid-thirties when their works were released in the 2000s, four authors who are the focus of this study had early literary and filmic success. One can assume the ideas they presented fell on fertile ground in German-speaking countries. Exploring the guilt of being related to one of the worst perpetrators, Claudia Brunner defines Phantomschmerzen through her memoir, Schweigen die Täter, reden die Enkel. In her novel Himmelskörper, Berliner author, journalist and German Studies professor Tanja 
Dückers created a fictional character who uncovers a meaningful secret that has influenced her family's life since the war; Uwe von Seltmann takes up the topics of longreaching corruption and hidden family identity in his novel, Karlebachs Vermächtnis; and, representing a different medium, the documentary film Winterkinder by Jens Schanze recounts a family's commitment to finally facing difficult family history.

These artists probe and investigate history in an effort to build and understand their identity. They do this work in a continuity of cultural production that began after 1945 and is anything but a desire to forget, deny or ignore. The authors are investigating and revealing individual responsibility for acts in the past; mourning; denying the assertion that the past can or should be resolved, even it if is "worked through;" and unrelentingly questioning in order to form a German identity based on knowledge and not simply acceptance. They have to do this work; German cultural producers come from no other tradition if not this one. They are showing themselves not only willing, but also highly capable of cultural production that calls on others to engage in the task as well. 
Chapter 2

Cultural Production in Continuity

"Theodor W. Adorno hat immer wieder zu großen öffentlichen Fragen Stellung bezogen." is a quote on the inner flap of a 1974 edition of his Eingriffe: Neun kritische Modelle. Indeed. Adorno returned to Germany from exile in the United States in 1949. A decade later, his thoughts about the country's confrontation with its troublesome past were memorialized in the essay Was bedeutet: Aufarbeitung der Vergangenheit.

One early offering by a preeminent German thinker to take a snapshot of what was considered important about the topic at the time, this essay is an example of the work of philosophers who subscribe to the brand of philosophy known as critical theory. Critical theorists, as described in the Internet Encyclopedia of Philosophy, busy themselves with testifying to problems in society and to the "extent and ultimate causes of the calamitous state of human affairs." Critical theorists call for no specific actions political or otherwise, but comment on elements of society that "are capable of being changed." Adorno is revered as one of the developers of critical theory (Fagan).

In his essay, Adorno was concerned with how the past was being dealt with by contemporary German society. He specifically wondered what the phrase, "working through the past" could mean. Evidently popular at the time, he terms this phrase a Schlagwort. Adorno comments that he thinks it probably means "to close the books on the past and, if possible, even remove it from memory" (Adorno, Critical Models, 89). Not only does Adorno dispute that this should be the goal, choking on the thought that, "The murdered are to be cheated out of the single remaining thing that our powerlessness can offer them: remembrance" (91), he also disputes that it can be done, because the past 
fascinates and holds too strong of a bind on the present. Although Adorno and the intricacies of his philosophy are beyond the scope of this investigation, the essay written on dealing with the Nazi past is a stone in the path of German reflection on its history. As such, it can be looked at to understand what such a preeminent thinker set as the guideposts for dealing with the past.

Written during what can be deemed the "first generation" of post-war society, Adorno's essay raises some questions that, one must admit, truly have been answered adequately by the simple passage of time, even though Adorno warns about relying on this very phenomenon as any kind of balm to the wounds of the past. Adorno comments that democracy in Germany at the time enjoyed a stronger foothold than it had during the Weimar era, for example (99). Germany has only continued this trajectory since 1959, a fact often used to answer critics today who argue that Germany could easily again fall prey to destructive, dictatorial leaders as it once did. Adorno also warns in his essay of the dangers from surviving elements of National Socialism (100). Again, an additional fifty-five years provides ample evidence that the threat, however real and however continually present, has remained on the fringes: Germany battles neo-Nazi groups and is sufficiently aware of its responsibility to do so. Even though much is always made when a racist attack occurs in Germany, to postulate that this is the beginning of another slide into fascism is generally dismissed for what it is - hyperbole.

Other points Adorno makes in his essay still prove relevant today, however, and especially relevant in analyzing the cultural production as reflection of society that is the subject of this investigation. Adorno postulates that, in contemporary German society, "there is much that is neurotic in the relation to the past" (90). Adorno claims people 
exhibit responses at the extremes, either "defensive postures where one is not attacked" or "an absence of affect in the face of the gravest matters" (90). Based on research done at the Institute for Social Research at Frankfurt University, Adorno heard "mitigating expressions and euphemistic circumlocutions" (90) by people when talking about horrific events, mass deportations and murder, for example. An oft-used line of reasoning in discussing unimaginable statistics was that "only five and not six million Jews were gassed" (90) and that a tallying up of casualties includes the numbers dead as a result of the bombing of Dresden (90). In Adorno's opinion, arguing at the extremes or avoiding looking soberly at the facts indicates the need for confrontation, something that had not adequately been accomplished.

Adorno appeals for education, for "enlightenment about what has happened" to "work against a forgetfulness that all too easily turns up together with the justification of what has been forgotten - for instance, parents who must endure embarrassing questions from children about Hitler and in response, indeed to whitewash their own guilt, speak of the good aspects and say that in fact it was not so awful" (100). Adorno is specifically addressing conflicts between the first and second generation that had started to appear in German society - conflicts that would prove to be of significant consequence and that would later have their own defining factors.

In addition, Adorno postulates that the individual must confront history and his place in it; as of the writing of the essay, Adorno claims German society suffered from a "collective narcissism" that "was severely damaged by the collapse of Hitler's regime, but the damage occurred at the level of mere factuality, without individuals making themselves conscious of it and thereby coping with it" (96). Adorno interestingly relates 
this situation to a theory from Freud and comments that the lack of processing at the individual level means that the individual has undergone no change: "Inwardly the defeat has been as little ratified as after 1918" and therefore disastrous desires still exist in the individual (96). Individual accountability, then, is another necessary step in the process of dealing with the past.

Most interestingly, today more than fifty years on, is Adorno's worry that the era of National Socialism will be forgotten and that this is a societal suffering: "The obstinate conviction of those who do not want to hear anything of it does indeed coincide with a powerful historical tendency" and an "atrophying" of the "consciousness of historical continuity" (91). To the contrary, interest in the era of National Socialism is keen today.

Of course there have been many who have contemplated Germany's attempts to deal with its history. Theodor Adorno is just one in a long line, but he commented with concern that the past not be forgotten, on the need for confrontation in those exhibiting extreme responses or apathy, on the generational conflict that would explode in German society a decade later, and on the need for individual account-taking. These themes continued to guide the work of cultural producers in the decades to follow and are relevant today.

Ernestine Schlant, German culture and studies scholar, offered her take on what and how the Holocaust should be presented in literature. Surveying the cultural production of post-war authors in The Language of Silence: West German Literature and the Holocaust, Schlant argues that authors who attempted to deal with the Holocaust in their cultural production did so in a way that maintained silence on the topic and perpetuated only denial and repression. Schlant surveys literature beginning immediately 
after the end of the war. The bulk of her work focuses on the first generation, represented by authors such as Heinrich Böll and Günther Grass, and the second generation, represented by many authors who wrote about their parents and how they grew up. Schlant offers criteria for judging whether authors have successfully represented the Holocaust, for whether they have helped their audiences to really get at the workings of the era. Schlant is a demanding critic. For purposes of this exploration, her survey will be summarized and confessedly simplified to a few points relevant to exploring the cultural production of further generations.

In the immediate post-war era, after the so-called Trümmerliteratur faded and when economic rebuilding became the focus of the day, trying to figure out what had happened in their society or paying attention to what any given individual might have contributed was not on the agenda for normal people, and evidently also not on the minds of cultural producers (Schlant 24). Schlant claims, "Knowledge of the Nazi past was channeled into denial and repression; this tactic canceled all hopes invested in a "zero hour" with its promise of a new start" (24). Schlant joins the views of other critics who noted that the literature of this era avoided all mention of Hitler and the Nazis, and most damningly, Schlant criticizes the literature for not featuring Jewish characters (25). The need to move on was great; and, of course, there was much to do to occupy German thought and capacity.

Schlant's analysis of first generation literature includes two works written by Heinrich Böll in the 1950s, the story "Across the Bridge" and the novel And Where Were You, Adam? Schlant criticizes the iconic German author for avoiding what really needed to be talked about: "As the seismograph of a people's conscience he reflected general 
postures; he, like most Germans, did not address issues that needed urgently to be confronted" (36). Schlant concludes that Böll lets readers off the hook, because his stories require no account-taking.

Schlant describes the narrator in "Across the Bridge" as a person in terrible personal turmoil. He claims he is not telling a story, and the story does not have any content anyway, although he must tell it. The story details the narrator's complete lack of knowledge of his complicity in the Nazi killings, and further, his lack of interest in knowing. He paradoxically thereby confesses to the crimes and represents what masses of people claimed was their story: lack of knowledge and, if any role, only a tiny one in the massive machinery of murder of millions that evidently no one knew was happening (27). Significantly, Schlant claims Böll allows his character no moral reflection on this stance. Thus, the audience that identified with this character is also not required to reflect and is let off the hook. Schlant proposes that this portrayal helped many to continue to avoid "individual accounting" (35) and the moral reflection arguably and understandably required of the German population.

The second story, And Where Were You, Adam?, is about a soldier who also avoids personal responsibility for anything by answering questions with a simple "I was in the world war" (30). In addition, this novel portrays Jewish people, from Schlant's perspective, in a problematic way - only as caricatures and unanalyzed stereotypes (32). Stereotypes are not individuals whose stories were snuffed out. Again, Schlant attributes Böll personally with an inability to break with accepted stereotypes, and in so doing, does not point the way for the audience to break with them either (36). One concludes that this 
is a demand Schlant makes from the literature attempting to address the problems of the Holocaust.

For Schlant, Böll represents the literature of the first war generation - those alive during the war, active in its execution, who then went on to produce culture that could have begun the task of processing and working through the past. Schlant's thesis is that the Holocaust and its horrific playground were only acknowledged by avoidance of the topic and the offering up of the same stereotypes that had been used to perpetuate the crimes. This generation missed the opportunity to begin the hard work of dealing with the past through denial, repression and unanalyzed thought. The work of confronting the past openly and honestly thus remains for future generations to tackle.

With parents guilty of repression, denial and unquestioned perpetuation of stereotypes, Schlant claims that the next generation dealt with the burden of the past no better than the first, although what they are guilty of differed from the first generation. As children of the war generation, Schlant claims, the second generation grew up thwarted on the topic of the Holocaust and its burdens (82).

This is the generation of the student revolts of the 1960s, which faded (the terrorist activities in Germany have to be seen as separate) shortly after the year their collective name, the $68 \mathrm{ers}$, memorialized (80). Plenty vocal with their anger, the students who brought their issues out into the public sphere nonetheless did so by simply attacking their parents (82). This generation hadn't participated in the atrocities of the Holocaust, but Schlant claims:

...when they wanted to confront the Holocaust, their leftist orientation protected them from the need to work through the Nazi past and its legacy. 
Their equation was simple: the Holocaust was an outgrowth of fascism and fascism was the most reactionary and most imperialistic development of capitalism. Therefore, the most important issue was the battle against capitalism. This position allowed them to attack the United States for its imperialistic war in Vietnam and, on the home front, the generation of elders who had embraced fascism, were now allies of the United States, and continued to practice capitalism in pursuit of the economic miracle.

Attacking the parents and expressing desire to not be like them was the focus of the student revolts. Schlant claims, however, that simply rejecting their parents provided this generation with a "shortcut" to distancing themselves from history's atrocities. Looking at the past or venturing to feel shame or sorrow or concern at all for the victims of the past was not on this generation's agenda, according to Schlant (82).

In addition to refusing to confront the past, this generation was intent on portraying itself as a victim of the war generation (83). The conflicts the authors present in their literature center on how they were raised and the abuse they suffered at the hands of an "authoritarian family structure of which most of these authors feel they are victims" (86). As novelists of future generations will also attempt, these writers present narrators who are trying to figure out who they are and what impact their parents - specifically what impact "breathtakingly barbarous child-rearing methods" (85) - had on them. Schlant claims the narrators are not interested in whether there is a connection between private actions and public or political actions, such as those that manifested themselves as the Holocaust (86). Critical thinking is not applied; only attacks are offered. 
This is not to say that the second generation did not explore the territory of the Holocaust past. Schlant presents analysis of a prominent genre of cultural production by authors of this generation, the 1970s and 1980s, by showcasing the novels of the Väterliteratur, "literature of the fathers." The criticism waged at how they explore the Holocaust centers on the fact that the Holocaust is only used as a bludgeon, representing the attack on the parent. The Holocaust is not the real problem the authors are working through, and as such, remains unanalyzed (86).

In these novels, a first-person narrator is prompted on the search for selfunderstanding by the death of a member of the parent generation who had failed to adequately provide information to the child while alive (86). The now adult child goes on a quest for understanding, and, according to Schlant, the novels are full of data to firmly root the parent in history, "...but the person the narrator remembers is never fully integrated into the social and political past" (86). Because the stories focus on mental and physical abuse suffered by the narrator, Schlant claims "the reader is left with a sense of work still to be done on the long road toward defining the self and coming to terms with an individual and a collective past" (87). The process is too personal, Schlant claims, to be applied to a "wider social panorama" (86).

Schlant also claims this genre of literature is formulaic in its approach. The formulaic set-up is predicated on a search for understanding of oneself, for building an identity and investigating the impact the parents had on that identity. The formula details a father who has returned to the family from the war broken and betrayed; the mother, who had done whatever was necessary to survive and now has to sublimate to the 
previous role in the formerly established patriarchy in the family; and, the children who grow up in a household structure that remains unquestioned.

Additionally, in these novels, the first generation sees itself as a victim in need of pity. Schlant claims "the sense of victimization and powerlessness has a long history in German thought" and that "the exculpatory and self-pitying undertones are the basso continuo in any discourse about the Nazi regime and the postwar period" (87). One can easily extrapolate that feeling pity for the first generation, for those who executed the war on whatever level, does not come easy to following generations.

Schlant also reviews literature that represents the end of the second generation authorship and notes that these novels "attest to an undiminished need to arrive at a definition of self against the background of the Nazi regime" (99). The past had not yet been "mastered." The themes remained.

The author Schlant looks at in detail is Hanns-Josef Ortheil, an author she claims is very thoughtful in his explorations. Instead of attacking his parents though, he writes of a narrator trying to figure out who he is in his society - "an uneasy consumer society in the act of covering up its past" (101). Along the way, differences between the generations, of course, arise, but Ortheil's focus is not on the parent-child-victim cycle or abusive parenting techniques. Ortheil writes of the search for understanding of the Nazi past and its atrocities, and of qualities in his society that landed it with such a horrific legacy (101).

Schlant praises Ortheil for portraying individuals whose characteristics go beyond the personal and into the societal, characteristics like the need for order and its possible beginnings after World War One (102). The characters in Ortheil's novels live through 
conflict, Schlant writes, but the conflicts also have societal implications and are ones that portray a desire to break from some of the earlier generation's rules and restrictions in favor of something new (104). Most importantly, the searching for something new by the characters is portrayed as necessary, as maturity, and as the passing of the torch to a healthier society (104). Schlant even muses that "Perhaps the past can be laid to rest only by a younger generation whose very identity and self-conceptualization depend on bringing this past to light, and only when this past is openly discussed, openly acknowledged, openly worked through" (105). Ortheil is also credited with naming the recognition that this work will have to be accomplished by future generations (106), a recognition that has direct bearing on the literature of future producers of culture.

One of Ortheil's characters battles storytelling of the war generation - the language used by people to obscure and distract from questions and accusations, and to forget for their own sake (108). Ortheil presents, in his work Hedges, a narrator who has to break through the storytelling to uncover his identity (108). The narrator cannot be lulled by the stories from his mother; he has to expose what is hidden to attempt to understand who he is, and to be able to move on with his own life (112).

Schlant criticizes the authors of the Väterliteratur for, in essence, letting the parent generation off the hook (120). While the parents are confronted, and the children need to be informed about the past, Schlant claims, the parents are not really forced to admit what they are hiding. Because they are not required to admit what they are hiding, the next generation can avoid recognition as well. This is Schlant's central criticism of literature by the second generation: while they do want to know, they only have marginal success; the history is still too painful to acknowledge fully; complete confrontation is 
not accomplished. Schlant also reminds her readers that Jewish characters, as individual victims, remain an untouched subject (122). Work for the third generation remains, and Schlant gives a nod to this conclusion. She claims Ortheil very keenly recognizes that the Holocaust cannot "recede into the past" (121), but has to be seen "as an ongoing, unsettling continuity" (121).

Growing up with such a complicated family legacy demands analysis. Schlant wants to see mourning for the victims by the characters presented in the novels - a proxy for mourning by the authors, and eventually mourning by society at large. Schlant illustrates the point made by Biendarra and others, that texts inform "about the culture they come from, while at the same time producing it" (Biendarra 11). Schlant also wants to see presentation of Jewish characters in and of themselves. While she sees Jewish characters used simply as peripheral characters, the atrocities committed by Nazis routinely not referred to, and no "horror or shame or sorrow" (Schlant 92), Schlant's harshest criticism is waged because the authors of the second generation allow the parents in the novels to speak for themselves, using every cliché imaginable, without being questioned or called upon to explain or defend what they are saying (92). Simply restating what they were thinking at the time, with no further reflection, Schlant seems to be saying, is not good enough. Answers must be sought and provided, and Schlant claims, a prime opportunity was missed. The opportunity was missed, because, in Schlant's view, the second generation was too weighed down with the "heavy baggage of anger and fury; indeed, the heavy baggage could serve as a demonstration of "good intentions" and simultaneously as an excuse not to look any further" (93). The first generation wasn't keen on providing information; the second generation was simply 
dismayed and accusatory; and, consequently, getting all the details and really understanding how society could go so awry would remain the work of further generations.

Peter Schneider offers the same criticism in his essay that appeared in Harper's Magazine in September 1987. A member of the student revolt generation, Peter Schneider is a novelist and social critic, continuing the legacy of cultural producers who routinely take a critical appraisal of their society. While writing in 1987, Schneider calls to the next generation in his article, because, in his view, the current generation is not measuring up.

Schneider writes in response to events in 1986 that disturb him, one of them being the "historians' debate" that was touched off by an article in the Frankfurter Allgemeine Zeitung written by Ernst Nolte. Schneider joins others in dismissing Nolte as a historian; he supports this argument with a few specifics, but openly states that his interest lies elsewhere. He is interested in "the opportunity it [the historians' debate] gave a new generation to advertise its view of history" (Schneider 50). He also posits that Nolte's article and the ensuing debate caught on in the wider public, because "it met still smoldering needs" (50). Schneider claims that those who took part in the public debate were themselves not the war generation, but the ones who were then in power, the politicians of the Helmut Kohl era, and that their goal was to distance themselves from the perpetrators. Schneider disputes that they can achieve this goal, reminding readers that these politicians spent time, for example, being educated by the National Socialists and taking part in some of the "years of comradeship, group solidarity, adventure" (51) that were part of the Nazi era. While perhaps positive for them, Schneider calls for a 
recognizing of the burden of the era as well, even if it is only the burden of "innocently acquired complicity" (51).

As a member of the protest generation, Schneider can claim to have belonged to those who saw themselves as truly untainted, the generation that wanted and was capable of a "radical new beginning" (52), representing the concept of the Stunde Null, when everything could be made anew. Although he claims in retrospect that he and his fellow protestors were naive, he calls attention to the very real desire for distance and dissimilarity to the parent generation. Schneider also assumes responsibility for being able to avoid asking the hard questions of the parent generation, given that the sons and daughters were busy rejecting them.

By avoiding real confrontation and exposure, Schneider claims future generations have been given license to exhibit "fascist behavior...unself-consciously" (54). He refers to murders by the RAF and describes shock in hearing the words used to justify their actions. Schneider openly admits that work remains: "The fact that...they aren't troubled by memories in their choice of words or methods shows they haven't elaborated their anti-fascism. For the moment, one suspects that the sins of the fathers are passed on both to the sons and the grandsons, and will continue to be until the sins have been acknowledged" (54). Schneider refers to members of the third generation, who were, at the time of the writing of the article, in their 20 s and 30 s, and calls on them to analyze their notions of anti-fascism. As his title begs, a "self-conscious German" would do no less.

Schlant and Schneider view the efforts expended to "master" the legacy of the German past, called for by the likes of Theodor Adorno even in 1959, as unresolved. 
Schlant, as literary critic, misses personal accountability, genuine mourning, and Jewish identity in the cultural production of authors. Schneider feels German society has developed a too easy-going approach with its past, leaving the hard work of owning up to it to future generations. Both believe work remains to be done. 


\section{Chapter 3 - Die Dritten in Literature and Film Schweigen die Täter, reden die Enkel}

Collaborating to publish Schweigen die Täter, reden die Enkel in 2003, Austrianborn Claudia Brunner and German-born Uwe von Seltmann met in 2001 on the occasion of a panel discussion entitled "Schatten der Vergangenheit," held in Klagenfurt, Austria. Two of the four members of the panel, Brunner and von Seltmann had been invited to describe their experiences of learning about and dealing with knowledge of Nazi relatives neither had known, Brunner's great-uncle and von Seltmann's grandfather. Although their paths had never crossed before, Brunner and von Seltmann had spoken frequently in public about their stories, and this forum provided another such opportunity (Brunner and von Seltmann, 13, 70).

Talking after the official panel discussion, Brunner and von Seltmann discovered they had two important things in common: as members of the third generation, they were the first in their families to break the silence about a Nazi relative, and they felt they were on a mission to help others who might wish to do the same. Schweigen die Täter, reden die Enkel is one contribution to this discussion.

Writing individual diaries, Brunner and von Seltmann detail events beginning in 1999 when Brunner was a student at the Universität Wien and von Seltmann was preparing to release his novel about a university student who discovers he had a brutal Nazi grandfather. Snippets in chronological order describe how each came to learn about the relative, what the knowledge means to them, and why they think their stories will resonate with others. For purposes of this investigation, Brunner's contribution is 
described in detail, and von Seltmann's is described in connection with presentation of his novel, Karlebachs Vermächtnis.

The "ever-present absence," the "elephant in the room," "phantom pain;" these are descriptions Claudia Brunner evokes in writing about her great-uncle, a man whose existence she was unaware of until she was 13 and someone who had not set foot in her homeland, let alone her hometown, in almost sixty years (Brunner and von Seltmann 18). Born in 1972, almost thirty years after the end of World War II, Claudia Brunner ventured to take up the history of her relative, the well-known Nazi criminal, Alois Brunner, for a biographical report in one of her classes at the Universität Wien in 1999. Brunner claims members of her family still stop in their own tracks when reflecting on their infamous relative: "Ja, ich bin mit diesem Alois Brunner verwandt - und alles andere als stolz darauf" (17). Mentioning the name Alois Brunner appears to cause no confusion in any stranger's mind. Indeed, the recognition everyone puts forward, the aura of secrecy, danger and "unspeakability" surrounding the mentioning of his name have stuck with her all her life and appear to be no different when, at the university, the lecture hall she occupies for a seminar goes silent when Claudia reveals who she is. The problem is that this seemingly well-known person, this infamous Nazi, occupies phantom space for her and her family. In the family album, in the face of a complete lack of information, not even the designation of "deceased" has been entered next to his name (9). Into the family's third generation, silence, a lack of knowledge and apparently no curiosity have been bulwarks to their identity: "Die Brunners hingegen hüllen sich seit mittlerweile drei Generationen in Unwissenheit oder Schweigen - fast alle" (17). This changes with Claudia Brunner's decision to research Alois Brunner to try to discover the true identity 
of the person who lies somewhere between the benign brother one of her aunts describes and the old man featured in a magazine interview who neither denies nor regrets his acts during the war (18).

Research for the university seminar project introduces Claudia to a man who very successfully "made career" in Hitler's horrific Europe. Alois Brunner would eventually go down in history as the "rechte Hand Eichmanns," the person responsible "für den Tod von 130000 Juden" (10). Already in 1931, at the age of 19, he had displayed his political convictions by joining the local branch of the NSDAP, the Nazi party, in Fürstenfeld, Styria (20). When the party became illegal in Austria, Brunner did not abandon the ideology, but left his homeland for Bavaria to join the Austrian Legion, the organization founded there that allowed members to continue to pursue their convictions (Garscha). By the time Austria was annexed to Germany in 1938, Brunner knew important future Nazis, including Adolf Eichmann (Brunner and von Seltmann 20), and had proved himself ideologically aligned with, willing to execute, and capable of the tasks ahead. Eichmann had founded the Zentralstelle für jüdische Auswanderungen in Vienna, which, as the name suggests, was a clearing station for all activities related to the removal of the Jewish people from annexed Austria, activities which became known as the Wiener Methode (Garscha). After Brunner returned to Vienna, he volunteered for the SS and became an "Eichmann-Mann" at the Zentralstelle shortly thereafter (Brunner and von Seltmann 21). By 1942, Brunner had been promoted to SS-Hauptsturmführer (23) and had been called to Berlin to instruct others in the Wiener Methode (21). In fact, Brunner was shipped to many places in Europe throughout his illustrative career to implement his successful methods. He held a personal goal to surpass in number every month the 
previous quota of deportations (27) and continued his activities most ardently until his successful escape at war's end in the spring of 1945 (28). The Simon Wiesenthal Center in Los Angeles attributes Alois Brunner with the deportation of 47,000 Jews from Austria; 44,000 from Greece; 23,500 from France; and, 14,000 from Slovakia. In meeting her great-uncle through hours and hours of research, Claudia Brunner gets to know the man who still topped the Center's most-wanted list of Nazis as late as 2013. (Zuroff)

What to do with this information was Claudia Brunner's next challenge. After crying and feeling utterly sick to her stomach at the site of pictures showing a man Claudia claims could be a cousin, she recognizes a personal change in her connection to the topic. Committing to personally not shy away from the truth about her relative, she keenly recognizes that her story is her country's story, and that she actually has more questions than there are answers in articles and books. Even though she is afraid, "...auch wenn mich dabei allerlei reale und irreale Ängste plagen..." (Brunner and von Seltmann 29), Claudia recognizes that her history, her family's history, is something she needs to process in the public sphere.

Unsure exactly what to do next, Claudia contacted Simon Wiesenthal. Wiesenthal survived the Holocaust and lived in Austria until his death in 2005. He dedicated his life after the war to uncovering information about Nazi criminals. Wiesenthal agreed to see Claudia at his office in downtown Vienna and made perfectly clear to Claudia that he did not hold her responsible for the crimes of her relative: "Der alte Mann ist sehr freundlich und stellt sofort klar, dass er nichts von Sippenhaftung und Schuldgefühlen hält, bevor ich auch nur eine Andeutung in diese Richtung machen kann" (30). Claudia states that their meeting did not last long; she and Wiesenthal had the same question for the other: 
"Is Brunner still alive?" Neither could answer definitively, so they exchanged contact information, and Claudia departed with the increasing awareness that the story would not be quickly wrapped up, even though she derived satisfaction from having taken these first steps (30).

In this realization, Brunner shares a hallmark attributed to the third generation: the past is not something to be "mastered." Claudia had become obsessed with history, and investigated and wrote in the era of the "Gedächtnisboom" (Ganeva 150), but quickly rejected the notion that she could do this work and find an endpoint to it: "...und die Rede vom angeblich zu ziehenden Schlussstrich wirkt auf einmal absurd. Die Zeit vermag zwar viele Wunden zu heilen, doch von Narben wird dabei kaum gesprochen" (Brunner and von Seltmann 8). She had to know about her past to understand who she is personally and to understand the society she lives in: "Je mehr ich zu wissen glaube, umso größer wird das Bedürfnis, noch tiefer einzudringen in dieses dunkle Kapitel der österreichischen Geschichte, die plötzlich auch meine Familiengeschichte und damit ein Teil meiner eigenen ist" (29). The past is part of her identity, not just something to close out with facts and figures.

By presenting the results of her research to her student colleagues at the university, Claudia took the next step of processing the information in the public sphere. She recognized that she opened herself and her work up to public criticism and comment, while recognizing that she deeply needed to talk about her relative in this forum (31). The room was completely quiet; during the discussion after the presentation, Claudia claimed to see in her colleagues a recognition and reflecting, indeed a reckoning, that had not been there before: "Die anschließende Diskussion ist erleichternd, denn neben Entsetzen 
und Betroffenheit kann ich unter meinen Kollegen und Kolleginnen auch Anerkennung und intensives eigenes Nachdenken wahrnehmen. Eine Rechnung ist aufgegangen, bevor ich sie gemacht habe. Und das nicht zum letzten Mal" (31). Going public about her relationship to a criminal of such notoriety could not have been easy. In this forum, however, it became clear to Claudia that, while her relative might have been more famous than some, many had family history that needed to be reflected upon and that her story resonated with others.

The weight of the story, however, is not to be underestimated. Not lost on her audience either, her professor, himself a widely published author on the topic of the Holocaust, spoke with Claudia after the presentation to ask if she had considered psychotherapy. The insinuation that she appeared to need psychotherapy unmoored Claudia for a time, and her defense was to diminish the story's impact (32). She liked to think of herself as strong enough to deal with the facts on her own, and that indeed the only option one has is to look at and accept them as they are. She found it laughable that confronting her family history would lead to the need for psychotherapy and rejected this suggestion. What she told herself is probably a common refrain: "...ich werde doch wohl mit dem bisschen Familiengeschichte im Rucksack allein fertig werden. Ist ja schließlich nur mein Großonkel, der vielleicht nicht einmal mehr lebt und den seit über 50 Jahren niemand gesehen hat. Und schließlich war es ja trotz allem doch nur ein Referat. Das wäre doch gelacht, wenn ich den Alten nicht wegstecke" (32). Claudia assumed she could return to living life as normal, even given the weighty nature of her findings. She lived "normally" up to this point with a vague inclination about her uncle's crimes. Her society 
functioned "normally" with crimes in its background. She did not think that specific knowledge would alter that course.

Knowing specifics did, however, affect Claudia Brunner, and part of the reason she published her diary was to elucidate her experience of living with feelings of discomfort, fear and pain - "...Unbehagen, Angst, ja auch Schmerzen..." (7) at the results she found and confronted. These negative feelings became part of her everyday reality, even two generations removed, and at times were easier to deal with than at others.

Brunner felt others might benefit from hearing how the information had affected her. She also wrote for those who discounted her reactions to her knowledge: "Diese Realität, die nicht immer einfach benennbar und angreifbar ist, wollen wir in diesem Buch auch anderen zugänglich machen. Jenen, die ähnliche Erlebnisse wie wir gemacht haben und sich darin wiederfinden können, aber auch jenen, die unsere Erzählungen für übertrieben, unser Unbehagen für gekünstelt halten" (7). Memorializing her experiences served both purposes well.

While information and fascination about the Holocaust seems almost inexhaustible, accountability of individuals had remained largely unexplored territory until the third generation took it up. Claudia's narrative is nothing if not personal; she does not talk about politics or the history of Nazism in her country; she only briefly touches on guilt of the collective as represented by the country; she focuses on personal interaction with the history, something arguably lacking in the research and particularly in the cultural production of German-speaking authors. Brunner fesses up to the horrific crimes of her great-uncle and decides to never hide that she is related to a mass-murderer 
again: "Von nun an würde ich keinen Hehl mehr daraus machen, mit einem Massenmörder verwandt zu sein" (29).

Brunner also shares that she holds a central personal conviction that the past even this far on - must be confronted. Remarking steadily through her narrative that the only possible way to deal with the past is to learn about and look at it head-on, Brunner described sharing this conviction with a group on the occasion of the 55th anniversary of the liberation of the Mauthausen concentration camp. Brunner exhorts: "Auch wenn es tatsächlich einen Unterschied macht, welche Schritte wir gehen, um uns unserer Vergangenheit zu nähern: Es ist unbedingt erforderlich, dass wir sie unternehmen!" (42). Claudia stated that one must learn to "approach" the past (42) for a variety of reasons: to recognize human weaknesses and boundaries; to set the tone for the present; to be able to trust in the future; and to be part of preventing any kind of recurrence (44). Brunner stayed true to this conviction and shared it with others on various occasions, as described in her narrative.

Relating on an individual level to the past and present Jewish community also features prominently in Brunner's processing of her family history, and this is featured in two ways in her narrative. In the first, she describes keen mourning for a small number of victims whose individual identity is memorialized in a meaningful way. Brunner decides, as sole representative of her family - because no others are interested, to attend a trial against Alois Brunner in Paris in 2001. Serge Klarsfeld and his family, well-known activists on the topic of Holocaust documentation, had initiated the trial; for the murder of 345 Jews, Alois Brunner would stand accused. Of course, Alois Brunner was not present. Claudia Brunner finds it "selbstverständlich" (55) that he stand trial, and cites as 
evidence the conviction articulated by Simon Wiesenthal that, if nothing else, such a process guards against forgetting and is important for young people (55). For Claudia Brunner, going to the trial is a must.

As part of the formal accusations against Alois Brunner, the names of the 345 murder victims are read off: "Nachname, Vorname, Geburtsort, Geburtsdatum. Nachname, Vorname, Geburtsort, Geburtsdatum. Nachname, Vorname, Geburtsort, Geburtsdatum. 345-mal. Ganze zwei Stunden lang. Und 345-mal sitzt niemand auf der Anklagebank, auf die ich trotzdem, wie viele der Anwesenden, immer wider hinstarren muss" (59). Claudia hears every name and imagines a flame going out; she feels the black clothing she wears is appropriate. She also comes to the conclusion that, even though her generation may not be guilty, they do carry responsibility. This responsibility required that she sit in the courtroom and bear witness to the crimes of the "anwesende Abwesende" (59) great-uncle whose name she shares and to mourn the individuals who were the victims. She is answering the critics like Ernestine Schlant who require this of those addressing the topic of the Holocaust.

In a second effort to connect to the Jewish community, Claudia took part in meetings between young Israelis and young Austrians in October 1999, an event organized by youth groups in both countries. The idea was to connect personally, to exchange stories of family legacies. What the individuals had in common was an interest in the past, an interest in living up to the title of the event, Breaking the Silence, interesting in and of itself fifty years after the war. The two groups found commonality in how they dealt with the past: the taking on of feelings of guilt; recognition of family secrets and taboos; loyalty to relatives who made confrontation with the past only 
difficult; the feeling of being part of a process to make things good again; and, lastly, fear in dealing with tough realities (33). Brunner describes that the short duration of the meeting was helpful; she full well recognized that her great-uncle should have the fate of relatives of the other participants on his conscience, and that is anything but easy to really acknowledge. Brunner takes this on her conscience, just like she takes on the fact that, in Austria today, right-wing extremists profess the same beliefs as her Nazi great-uncle. A book at the gathering detailed the affiliations of some of these people, and Brunner acknowledges "ein dunkler Schauer, ein Schatten, der mich nicht mehr so schnell verlässt. Nicht immer ist er sichtbar, aber er kann immer wider dorthin fallen, wo ich gerade stehe, und eine Zeit lang für mich auf unangenehme Weise spürbar bleiben" (36). Brunner is acknowledging, without going to extremes, that she experiences the past as continuing to throw its shadows on the present, not as something that is left behind. Her answer to that burden is to investigate and continually confront, as is evidenced by the activities she willingly engaged in, one product of which is her memoir.

Brunner experiences another familiar theme of die Dritten: generational dynamics in action in her own family. As Mila Ganeva describes, die Dritten are the third generation, not just because of their age or that they have parents or grandparents that fall into the first and second generation categories, but because of the "consciousness of and attitude towards the past and the specific position they occupy in the contemporary, postunification literary context" (Ganeva 151). Brunner's parents, as members of the second generation, are memorialized in her narrative. Although Brunner relates no vicious attacks by the second generation on the first (perhaps primarily because the first generation is largely absent), it can hardly be said the second generation deals in a 
healthy or up-front manner with their history: no one has ever really talked about the Nazi relative. "Mein Vater...hatte von der Existenz seines Onkels mehr Nichtwissen als Wissen gehabt, begrenzte jener doch eine absolute Tabuzone, in die sich auch die nächsten Angehörigen nicht einzudringen getraut hatten" (Brunner and von Seltmann 76). Of course much is known about him, hence the results achieved by Claudia's research, but personal interest, indeed personal reckoning, had apparently been absent until Claudia took up the story.

Claudia feels, too, that her parents would have preferred she not investigate the past even now; in other words, keeping the silence they had fostered while raising her was preferred: "Ganz im Gegenteil, mit einem Gemisch aus Sorge um mich und Angst vor der eigenen Konfrontation damit hätten vor allem meine Eltern es wohl lieber gesehen, ich hätte diesen Weg niemals eingeschlagen und mich stattdessen um harmlosere Dinge gekümmert" (74). Even with her father, with whom she regularly discussed politics as part of a "lebendigen familiären Diskussionskutur am Mittagstisch" (74), words to discuss the difficult family member could not be found. Brunner attributes this inability to discuss the past partially to family loyalty, "familiäre Verbundenheit" (75), but also simply to a different perspective brought on by differences in their realities - one from the second, one from the third generation.

Brunner's grandfather, Alois Brunner's brother, is mentioned twice in her narrative: once to describe him as a "man of few words" (60), especially about this topic, who apparently never saw his brother again after Alois Brunner fled at the end of the war; and once to describe events that unfolded when he died. Interestingly absent is any mention of his participation in the war. The first generation is further represented in 
Brunner's narrative by the wife of Alois Brunner, Anna, who lived in Vienna at the time, and with whom Claudia claims her family never had contact (76). The first generation provides no access to family history. Brunner's experiences with her family members eerily recall Ernestine Schlant's view that the Holocaust was mostly dealt with by the first and second generations with denial and repression.

With her narrative, Brunner claims her place in the Enkelgeneration. Her writing rejects any notion that the third generation might be able to interact easily with the history, given the time that has passed, as had been thought possible by critics and scholars reviewing cultural production from this era of authors (Ganeva 152). In fact, Brunner concludes her narrative with a diary entry from April 2003, several months before her work is published, by describing that she has decided to speak with a psychologist, and that the psychologist agrees she has much to deal with. While always feeling that confronting the past was the only way to go, the weight of the truth has unmoored her, although she clearly sees her current state-of-mind as part of a process: "Es ist wieder einmal vorbei mit der Ruhe vor der Sturm, und der Zeitpunkt scheint noch nicht gekommen, an dem mir die Wiederherstellung der inneren Sicherheit gelingen wird" (Brunner and von Seltmann 89).

Brunner's narrative provides no further conclusion other than to offer a view of the process of dealing with the past that the first and second generations had not been able to do: she professes that facing history is necessary; that the crimes have to be owned up to; that mourning for the victims is part of the process; and, perhaps most significantly, that the past is not to be "mastered," but consciously lived and dealt with. 


\section{Chapter 3 - Die Dritten in Literature and Film \\ Himmelskörper}

Part Väterliteratur, part Familienroman, part Bildungsroman, Tanya Dückers' novel Himmelskörper, published in 2003, connects all three and defines the genre of Enkelliteratur, thereby making the intentions of the third generation clear: secrets must be exposed, questions answered, the past absorbed in one's being. Only through this process can a whole individual - one with a clear understanding of the surroundings and an intact identity - be formed.

With all that Dückers has to accomplish, she structures her narrative cleanly. Each chapter is a story in-and-of-itself, even if references to other past, current and future events invade a particular train of thought. Dückers makes immediately clear to the reader that she is interested in history and continuity. She reaches back to 1892 for the historical foundation of her main character's current project, a new cloud atlas to replace one compiled long ago in 1894; and she invokes the iconic Goethe on the second page of her narrative. Additionally, Dückers presents a scientist as her main character, Freia Sandmann; the narrative will be about the pursuit of knowledge. Finally, the theme of actively reflecting on childhood and the harbored secrets in the family is introduced right away. Freia indulges in her central activity of the novel, reflection on the past, to relate how she often saw her father write notes to "God," throw them in the sea and claim the contents as his secret in the face of questions from his children. The narrative is framed in the first few pages. The themes of history, knowledge, family and secrets accompany the reader all the way through. 
Dückers reminds the reader that the Väterliteratur genre was not just about sons trying to understand the impact fathers had on lives. Freia is a daughter most interested in the secrets her mother and grandmother harbor. In contrast as well to the formula followed by authors of the Väterliteratur as described by Ernestine Schlant (86), the occasion for Freia's quest is not a death of a parent, but rather an impending birth of a child. Freia is pregnant, about to become a mother to a daughter, and this is the occasion that spurs her to try to fill in details she has always questioned. In the tradition of the Väterliteratur, however, this significant life event has brought Freia to a point when she seeks answers.

When Freia travels, she takes along pictures of her family, and the most important people in her life are introduced to the reader through these pictures: Peter, her father, whimsically described; Mäxchen, the injured war veteran grandfather, leaning on crutches and perhaps speaking with "Silberlügenaalen" (Dückers 9), a lovely example of Bildersprache; Jo, camera in hand and wearing a colorful jacket; and Paul, Freia's twin brother, untrustingly looking at his father. In a nod to the current, unattached generation, and in sharp contrast to her mother and grandmother who own many photo albums, these pictures are described as "enough;" Freia owns no photo albums and expresses satisfaction in the phrase: "Ein Foto jeder Person. Das genügte" (9).

After these descriptions, Freia makes the first mention of her mother. The reader is still trying to orient to the story and the characters, but Dückers' set-up is effective. Freia returns to the picture of Peter, her father, and reflects on the secrets he held during her childhood. He would disappear after dinner, only to return the next morning, hair in a tangle and coat covered with leaves, to describe that he had been in the forest and spoken 
with elves. He would then draw the elves for the children, and the children would ask their mother to draw something. Freia describes: "Meine Mutter lachte nur...'Das kann ich nicht', sagte sie verlegen" (9). Even the simplest line on the paper is something outside of her ability; of course the children find this questionable, and Freia comments about her mother: "Sie glaubte immer, etwas nicht zu können" (10). This reference to "meine Mutter" is casually slipped in, and through this almost slight-of-hand, the author brings in the figure that holds the key to her narrative. The presence of the mother, usually strong in a daughter's life, is defined through her absence: "Ein Foto jeder Person" (9) mentioned no mother; she is behind the scenes, embarrassed and without abilities, whether true or self-imposed is unclear.

Further, the characterization of the mother in comparison to the father drives home the point - the father is a strong personality, one who soaks up all the attention: Pe-ter. Pe-ter. Pe-ter. Peter, der Kopfschmerzen hat, den eine Wespe gestochen hat, der am Strand auf eine Qualle getreten ist. Der am ersten Urlaubstag in Dänemark alle mit seiner schlechten Laune quälte, weil er keinen Zigarettenautomaten neben der Blockhütte fand. Der seine lustigen Geschichten schrieb, bis man vor Müdigkeit, und weil auch Lachen auf die Dauer anstrengend ist, nicht mehr konnte. Weder Paul, der aus dem Stegreif Geschichten erfinden konnte, noch ich, das Mathe-As und Knobeltalent, und schon gar nicht meine Mutter, von der jeder glaubte, sie und ihre Frauenzeitschriften, ihren Kräutergarten und ihre Königsberger Klopse in- und auswendig zu kennen, standen im Mittelpunkt unserer Familie. Nein, es war immer Peter. (10) 
The father, through all of his eccentric displays, quirks, joie de vivre, and exciting secrets, would seem to be the central figure of the narrative and the family history. Only the careful reader wonders why this image of him is subtly set up as a contradiction, and why, earlier, there was no description of a picture of the mother. By evoking the father's strong personality and dismissing the mother's personality, Dückers intelligently hints at the core of the story - the inconspicuous mother. As if reflecting Ernestine Schlant's analysis of early Holocaust literature, the mother is truly a very strong presence through her absence.

Not only is Freia missing a picture of her mother when she travels, she is missing a picture of a cloud she has spent her university career trying to capture. The opening two paragraphs deliberately confuse the reader: Dückers evokes a perfect image of Freia, travelling in a train, frantically searching for "das Foto," even though the reader does not know until several pages later precisely which photograph is missing:

Unruhig durchwühlte ich meine Reisetasche, durchblätterte einen Notizblock, eine Zeitung, schlug meinen Paß auf, suchte zwischen BahnCard und Bibliotheksausweis, zwischen Thermoskanne und getrockneten Früchten das kleine Schwarzweißbild, das ich gestern aus dem FotoSchuhkarton genommen und auf meinen Schreibtisch gelegt hatte. Ich biß mir vor Wut auf die Lippen. (7)

The paragraph immediately following details a formal request by "Die Internationale Meteorologische Konferenz" for pictures of clouds, and the reader imagines the picture Freia searches for so frantically is a picture of a cloud. Combining the image of the mother with the elusive cloud of Freia's career is no accident; Dückers evokes this image 
purposefully. Freia's mother and the cloud are two mysteries in her life; she is on a quest to track them both down.

The father of her child eventually calls Freia's attention to the fact that she travels with no picture of her mother; Freia is embarrassed. She spends much time trying to find an appropriate photograph and finally picked one the day before her thoughts are revealed to the reader, who finally gleans that this is the picture Freia was searching for in the train.

The photo Freia carries with her represents the confusion she feels around her mother. The shot is of Renate, at about the same age as Freia currently, "ausnahmsweise nicht nur menschliche Haltevorrichtung für niedliche lockige Kleinkinder, sondern einmal nur sie selbst" (13). Freia comments that the picture must have been taken without Renate's knowing, because she looks natural and at ease; Renate is smiling.

Freia comments that it looks like a grove of pines, "ein Heer von dunklen Zwergtannen" (13), has stepped back out of respect for her mother, who is swinging on a swing. This fits with Freia's image of "mother," a commanding person, one on whom one is dependent but also one who must be pushed away as part of the growing-up process, quite elegantly described as: "Mutter: Das ist eine personifizierte Nabelschnur" (14).

Freia does not see her mother in a commanding or strong role, however. In fact, Renate is quiet and content to never be in the spotlight; the children always felt they needed to be a bit worried about her; and the fact that she was strong enough to work as a therapeutic masseuse confused the family. Freia comments that her mother had a great ability to fade into the background: "Sie stand da vor der Fensterbank, und wenn sie nach zehn Minuten ein Wort sagte, ich lag längst mit einem Buch auf der Couch, fuhr ich 
zusammen. Meine Mutter hatte ein enormes Talent im Nicht-anwesend-Sein entwickelt" (15). Again, this description is in contrast to the father, who always only left traces of his presence behind, with whom Freia spent hours talking and with whom she eventually even shared secrets.

Freia finds her mother boring and, most damningly, unsuccessful in the motherly duties the children could carry forth into the future. Neither Freia nor her brother learned skills like cooking or how to make a bed; Renate gave up when the children showed no interest, and this failure is of no small consequence. Freia's mother wanted to fade into the background, and for her daughter, she had in many ways succeeded. Tears come to Freia's eyes as she reflects on the disconnect between the person the picture would seem to portray and the person Freia thinks she knows.

The final scene of the opening chapter of Dückers' novel leaves nothing about the mother-daughter relationship unclear. Unbeknownst to each other, mother and daughter are travelling on the same train through the city of Hannover. All of a sudden, Freia sees her mother on the platform, but is behind soundproof and thick windows that are not to be opened: Freia cannot get her mother's attention, and they miss each other. The fact that mother and daughter are not close enough to have figured out they were going to be on the same train reflects for Freia the relationship to her mother; she is deeply saddened and feels helpless. She also hopes for a wild moment that her mother is secretly meeting an old lover, doing something for her own self for a change, being a woman instead of "only" the wife, mother and daughter of others. Either way, Freia is struck by the experience: "Wir haben uns verpaßt, diese Tatsache war so unmittlebar und deutlich - als unsere Züge sich in verschiedene Richtungen in Bewegung setzten, mußte ich laut und 
falsch lachen" (20). One senses mother and daughter have not only missed each other at the train station.

In fact, Freia describes to her brother shortly thereafter how she missed their mother at the train station and reveals what is really bothering her about the experience. Brother and sister spent long hours talking together. They are twins and obviously deeply connected, despite a break they successfully bridged, the details of which the reader only learns much later. Paul asks his sister why their mother has been a source of so much preoccupation recently, and Freia points to the obvious, but with a twist:

'...es hat mich neugierig auf sie gemacht...seitdem ich also weiß, daß ich selbst Mutter werde, muß ich sehr oft an Renate und auch an Jo denken. Es gibt wo viel Ungeklärtes in unserer Familie, das mir plötzlich keine Ruhe mehr läßt. Als hätte mir meiner Schwangerschaft eine Art Wettlauf mit der Zeit begonnen, in der ich noch offene Fragen beantworten kann...ich weiß auch nicht genau, woher meine Unruhe stammt...vielleicht ist es ein unbewußter Drang, zu wissen, in was für einen Zusammenhang, in was für ein Nest ich da mein Kind setze...' (26)

Seeing herself as a link in a chain of her mother, her grandmother and even her great-grandmother, all pregnant at some point, Freia acknowledges that this chain represents a structure she has never been comfortable with: "Plötzlich war ich Teil einer langen Kette, einer Verbindung, eines Konstrukts, das mir eigentlich immer suspekt gewesen war" (26). Embodying the continuity represented by this chain, Freia also recognizes key differences, however. She is giving birth out of wedlock, had studied at university, and most significantly for the unfolding story, was not born during a war. 
Both her mother and grandmother were born "im ersten Kriegsjahr" (26). With this reference, and one to the "Bund Deutscher Mädel" that follows right on, the reader glimpses Freia's musings. In Dückers' style, however, both references are not explained at this point in the story; the reader files away ambiguities that need to be clarified, but knows that the story will most likely involve Germany's troubled war past and the influences of that past on the current generation.

The different way the three generations - Tätergeneration, die 68er, die Enkelgeneration - relate to the war years unfolds through the whole of Dückers' narrative. A story early on expresses some of Freia's confusion as she tries to make sense of conflicting images she experiences. When Freia was young, her grandmother would braid her hair and show her pictures from her youth. The pictures were of the grandmother, Jo, and her sisters "in ihrer BDM-Zeit," "...mit langen blonden Zöpfen...brav in Reih und Glied" (27), and self-described as representing "the happiest time of her life." The reader sits up and takes notice, especially as Freia compares herself to her grandmother at the same age.

Being taught in school for the second time about the "NS-Regime" (28) and busy, along with her brother, pummeling the adults in their lives with questions about what they were learning in school, Freia found this time of her life best represented by the slogan "Null Future" (28), locating her firmly in time and place of West Germany in the 1980s; Freia is a member of the follow-on generation to the 68ers, some of those being pummeled with questions. The slogan is anything but positive, and she claims "Es war nicht die glücklichste Zeit meines Lebens" (28). How the "BDM-Zeit" could have been the best of her grandmother's life remains an open question, for Freia and the reader. Why 
this period was not the best of Freia's life, and how much of that has to do with the harsh stories she was dealing with from school, also remains an open question.

Dückers herself can speak with experience of the attitudes of the "Null Future" generation. Born in 1968 in West Berlin and "...erzogen von 68-er-Eltern, rundum politisiert" (Sehen, suchen, schreiben), Dückers wrote her novel in first person. While not strictly autobiographical and therefore falling into the category described by Ernestine Schlant as "autobiographical fiction" (Schlant 84), Himmelskörper was published when the author was 35 years old and represents for Dückers the counter to the accusation that "her" generation looks at the world apolitically or uncritically (Sehen, suchen, schreiben), or that they would not be interested in the history of the Hitler era (Der nüchterne Blick der Enkel). One of Dückers' stated goals in her novel is to have the main character throw a "sober look at history" and to ensure an "Authentizitätsdünkel der Älteren" not appear (Der nüchterne Blick der Enkel), simply because this third generation did not experience the era directly. Dückers comments clearly, in her work and in interviews about her work, that, in the face of the giants of the literary world who write on this topic - Günter Grass and Martin Walser, for example - this generation has an opinion about the traces left behind and intends to share them (Sehen, suchen, schreiben). Dückers' extensive research into the era shows up as the results of Freia's quest for understanding of her family's history.

Brother and sister chew on all the family history during long evenings of shared conversation: "Wir entwarfen verwegene Hypothesen, ich zitierte Bücher und Romanhelden, sprach über Renate und Westpreußen, Peter und die Elfen, über den Bleichen See und unsere Mittelinsel, natürlich über jenen besonderen Abend mit meiner 
Mutter, an dem ich zum erstenmal von Rudolf erfuhr..." (Dückers 28). Paul is Freia's twin, and her complement. While Freia is busy with the scientific, Paul is an artist and busy with aesthetics. As youngsters living outside the city of Berlin, they only needed each other:

Die Welt, die für uns am Stadtrand anfing, war perfekt: Ein Junge und ein Mädchen...der eine konnte schon gut schreiben, die andere war gut im Kopfrechnen, der eine konnte sich Geschichten ausdenken, die andere die Namen der Sternbilder aufsagen...der eine aß gerne die obere Hälfte vom Brötchen und unreife Bananen, die andere die untere Hälfte und halb matschige Bananen - wir beide vermißten niemanden und nichts, wenn wir zusammen am Bleichen See vorbeiliefen. (68)

Dückers captures well the dreamy and carefree world of childhood and portrays a typical and familiar German family (a nod to "West" German must be made.)

Because the narrative is also part Bildungsroman, Freia reflects on how some childhood images are replaced over time and how some unique elements experienced by children in Germany become part of the picture: "Später einmal würden dieser Wald, dieser See und dieser Himmel von gefallenen Engeln, einst Elfen und dann nach Schweiß riechenden Frauen, bevölkert sein, von viel zu vielen, zuviel Gestank, Gerüchen ..." (69) The children's father took them on day trips into the city to fly kites on the Teufelsberg; the children thought up ways to slay the ghosts that would otherwise tangle the kite strings. The children had no trouble attributing the name of the hill to these nasty ghosts; only later did the name take on another meaning, one with a whole other set of daemons to conquer: 
Irgendwann später würde der Berliner Teufelsberg sich als 25-MillionenKubikmeter-Schuttberg entpuppen, der seine Entstehung dem Zweiten Weltkrieg zu verdanken hatte - was seinem Namen plötzlich eine ganz andere Note verlieh. Doch noch waren wir so klein, daß wir weder etwas über den Krieg wußten, noch überhaupt eine Vorstellung davon hatten, in welchem Land wir wohnten. Wir wohnten "am Stadtrand." Das war unsere Welt. (69)

This is an example at Dückers' skill at combining private and public, personal and shared, biographies, and fulfills a requirement she finds important for the processing of history. One must find some personal access to events to be able to process them (Der nüchterne Blick der Enkel).

For the children, the lake on their land, the so-called Bleicher See, with its island in the middle, is a source of unending activity. The lake had peculiar inhabitants: Grübelmonster, Futterneidhaie and Silberlügenaale. Most importantly, however, the children decide their grandfather's leg must be at the bottom of the lake.

Evoking a well-known war image, Dückers' war veteran, Mäxchen, is an amputee. The children see their grandparents regularly, but Freia cannot remember how she came to be aware of the grandfather's condition: "Ich erinnere mich nicht mehr, wann ich Großvaters geheimnisvollen Stumpf zum erstenmal bewußt wahrgenommen hatte" (78). Not especially bothered by his condition, the children are aware of the advantages he enjoys because of it: he pays less admission, can park close to the entrance of places, and doors are opened and the way made clear for him. Freia muses, "Großvater schien eine Art Bundeskanzler zu sein" (78). But where the leg is fascinates the children. Predictably, 
the "geheimnisvoller Stumpf," and all its complicated associations, has not been a topic for discussion in the family.

Dückers puts on full display the generational dynamics surrounding dealing with the Second World War when she describes how the children make up answers to their questions in the absence of information from the parents or the grandparents. Naturally children are fascinated by something as exotic as a missing leg; Dückers captures this aspect of childhood appropriately. The children also play-act "prosthetic." They ask how their grandfather lost his leg and are told it happened in the war, but nothing more: "Was das bedeuten sollte, wurde uns nicht klar. 'Krieg' schien jedenfalls ein schrecklicher Ort zu sein, eine Gefahrenzone, in die aus irgendeinem Grund nur Männer kamen. Es hieß noch, daß 'Großvater hart gekämpft und Großmutter lange auf ihn gewartet habe' " (78). "Krieg" supplies unending creative possibility in the absence of concrete information, and the children routinely make up detail-rich stories.

While the children are young, the stories cause the parents and grandparents to chuckle and turn away. This works for a while, although the children are increasingly offended at not being taken seriously. "Großvater lachte immer in sich hinein, was eher wie ein leichtes Husten klang, wenn wir ihm unsere Überlegungen schilderten. 'Ach, Kinder', sagte er manchmal kopfschüttelnd, was uns verwirrte und hochnäsig vorkam" (79). Jo is amused at the creativity the children exhibit, especially when she hears stories about the creatures that might have stolen the leg. But she brushes off the children's questions as well and attempts to distract them with a chore. Freia describes that she and her brother really wanted clarification about what happened to grandfather "im Krieg," and so they continued to ask. They were highly annoyed "daß die Erwachsenen entweder 
nur riefen 'So oder so ähnlich könnte es gewesen sein' wie Jo oder gar nichts sagten wie Renate oder wie Peter einfach nur: 'Könnt ihr noch mal von was anderem reden?

Großvater hat sein Bein im Krieg verloren, wie, weiß ich auch nicht.' Manchmal stöhnte auch einer von ihnen: 'Kinder, ihr fragt uns Löcher in den Bauch!' " (82). The third generation asks so many questions, because they feel they deserve answers; the second generation is silent or perhaps uninterested and uninformed; the Tätergeneration is uncomfortable and likewise unforthcoming. While these coping strategies temporarily work on children, it is clear they are not a long-term strategy.

Before childhood innocence is left behind completely, the tension caused by silence and avoidance of direct answers between the generations in Dückers' novel ignites. Paul has decided to share with the adults one more time a story about grandfather and his missing leg. The fairy tale is about a boy and a girl who can speak to animals and who each wear a handkerchief around one leg. Freia claims alone this detail "schien Jo aufzubringen" (83). The children travel through an especially dark forest; bloody birds fell from trees; clothes lay everywhere; shots were fired; a city burned in the distance. The forest was called "Russia" and it was full of people Paul couldn't quite name - "so ähnlich wie Party und Parmesan. Parmisanen, glaube er" (83). They shot at the children and calamitous devastation ensued. At the end of the story, the adults are shocked. Jo attacks Mäxchen with the question " 'Was - um - Himmels - willen - hast du ihnen alles bloß erzählt?' " (84).

Mäxchen comes clean and, embarrassed, explains that he had been reading a fairy tale to the children one day when they asked again what had happened to his leg. He tries 
to make light of the incident still, but he is pushed too far. He finally rises up, explodes, and states clearly that he finds it ridiculous that his grandchildren know nothing:

'Ich hab ihnen mal wirklich was erzählt, Johanna! Von Hitler-Deutschland, vom Rußlandfeldzug, von meinen Erfrierungen, vom Wundbrand, vom Lazarett, von meinen Kameraden, die's nicht überlebt haben. Herrgott! Sie glauben immer noch, obwohl sie ab Herbst in die 4. Klasse gehen werden, daß mir eine, was weiß ich...' - er machte eine hilflose, ausladende Geste -, 'Riesenschlange oder so was das Bein abgebissen hätte!' (84)

He glares at all in attendance, especially those "die nicht das gleiche erlebt hatten wie er" (85). With his out-of-character outburst, Max clears the room. Only Renate stands silently at the window, as she always does in times of conflict. Freia states that, for the first time, she recognizes that her grandfather had led a different life from the one she knew: "...und sagte dann plötzlich mit völlig veränderter, fester Stimme, die mir zum erstenmal deutlich machte, daß mein Großvater ein ganz anderes Leben vor seinem Ohrensessel-Dasein geführt hatte" (84). With his outburst, Mäxchen highlights how inadequate silence and avoidance really have been as strategies for dealing with questions about the war era.

Mäxchen wants the next generation to know something, anything, about the era, but he is also begging to be understood and recognized for his experiences; no one disputes that he lived through a hellish time. Dückers is giving a nod to the fact that "knowing" indeed goes both ways. The emotions of those who were actually in the war have to be dealt with if an open and honest conversation about the war and its consequences is to be had. Silence serves no one well. 
Ernestine Schlant claims that earlier novels of the genre of the Väterliteratur often portrayed the broken war veteran as someone who saw himself as a victim - a victim of many things: betrayed ideals, broken promises, alienation. Being a victim after the war was useful - victimhood allowed many to avoid taking responsibility (Schlant 87). Mäxchen does not portray himself as a victim in this interlude; the children do not necessarily see him that way, but they do feel sympathy for him, which expresses itself somewhat problematically: "Wir sprachen leise miteinander. Man hatte auf Großvater geschossen. Armes Mäxchen. Er ging mutig nach 'Rußland', blieb sogar einen ganzen Winter, anstatt zu Hause Weihnachten zu feiern, er harrte aus, damit alles wieder 'wie am Schnürchen' lief, und als Dank dafür schoß man auf ihn. Der Russe mußte ein besonders fieses Monster sein" (Dückers 87). Without the full picture, which would be provided by open and honest, multi-sided explanation about the war, the children are left to draw conclusions that let their grandfather completely off the hook. Cleverly, Dückers shows with this example that silence, avoidance, and other irresponsible coping strategies from earlier generations have led to unfair and false perceptions that deserve to be corrected.

While the explosion is only personal and leaves more questions open than answered, the children again win an access point to the past. "History is never objective," Dückers stated in an interview about her work; the "persönlicher Zugang" is important (Der nüchterne Blick der Enkel). Without the third generation, the story would get stuck in Mäxchen's telling of it, stuck in the first or second generation narrative, which clearly leaves much to be desired. The grandchildren must take it from here.

The family stays tense after this display, and Dückers portrays what Adorno would have described as "intense affects where they are hardly warranted by the 
situation" (Critical Models 90). It becomes a topic, what exactly to tell the children, just how much they could handle. Jo and Renate are uncharacteristically gentle with each other; they speak in whispers when they think they are not noticed; and, Renate does not stop smiling, to the point that Freia is worried about her. But as time passes, the children still want information and they ask probing questions. Freia, ever the researcher, wants to know what the bombs sounded like: "Ich löcherte Jo immer weiter, wie denn die Bomber geklungen hätten - wie das Donnern eines Gewitters, wie ein Auto mit kaputtem Auspuff oder eher wie die Knallfrösche, die wir am 1. April unseren Lehrern auf dem Hof hinterhergeworfen hatten?" (Dückers 88). Jo, spying a bothersome fly in her kitchen, cries all of a sudden " ' Nun reicht's aber mal!' " (88). She hunts the fly with a fly swatter, gets a crazed look in her eyes and attacks. Given the title of the chapter, "Der Krieg ist eine Fliege....," one assumes Jo is a bit overloaded with it all and is uncomfortable with these children who will not let the topic go. In this scene, the reader sees that the war era and how to talk about it is clearly an open wound for all in the family.

Even if the era is an open wound, Jo had worked some things out in her own mind, and she will not be diverted from them. Jo displays a trait discussed by Ernestine Schlant in her analysis of Hanns-Josef Ortheil's story Hedges: the use of language to tell a story that hides what really needs to be talked about, like "a cover for secrets that have to be hidden" (Schlant 107). One cold January evening, the family sat by the fire; Jo took the stage, and she started down a well-worn and familiar path to share information about her homeland, which allows her to express frustration at what she sees as ignorance of the youth: " 'Ihr lernt ja heute nichts mehr über eure Heimatstädte, ihr nehmt ja nur noch den Marianengraben und die Antarktis im Erdkundeunterricht durch. Je weiter weg, desto 
besser. Bloß nicht Deutschland' " (Dückers 100). She came from Königsberg, fled via Gotenhafen in twenty-degree-below-zero-winter weather, and was deeply affected by the destruction of Königsberg in August 1944: " 'Und dann haben sie alles in Schutt und Asche gelegt' " (100). She loses herself in front of the children in a little bit of a history lesson; the history is from her perspective and only on her terms, it must be noted.

Not only is the story extremely one-sided and from a very narrow perspective she makes no mention about why her city had been destroyed or the fact that both these cities had histories before and after the events she cares about - Jo used the same expressions, the same pauses, the exact same words every time she told the story. "Die Stimme meiner Großmutter zitterte nicht oder nicht mehr bei diesen Erinnerungen; zu oft hatte sie diese zurechtgelegten Sätze wiederholt" (100). Jo hides safely behind these sentimental, "zurechtgelegte Sätze."

The destruction of the city is, of course, a tragedy. What strikes the reader, however, is how much more there is to the story than what Jo decides to share. This story has not been looked at critically since the war. No new perspective has been added; Jo does not even give so much as a nod to the fact that these cities now have new names, because they are now cities in other countries. The reader is shocked to hear that Jo thinks of Königsberg as part of Germany or that tactics used by the Russian army in the destruction of the city deserve focus. With this interlude, Dückers highlights the problematic perspectives of members of the first generation who have not budged from their stories to reflect critically on the era.

By and large, the family allows Jo to proceed unchallenged, but sometimes it is too much for Renate to take. While Freia comments that Renate never spoke unprompted 
about the past, and stole to the window when the conversation turned to the topic, she knew quite a lot: "Sie schien dennoch die einzige zu sein, die sich für Publikationen über den Krieg interessierte, insbesondere für den Rußlandfeldzug und für die Flucht aus Ostund Westpreußen" (98). Renate intermittently decides to challenge her mother, and to a certain extent, her father, on some of their unexamined perspectives. The reader can tell this has been done many times in the past; Renate is a 68er, after all. After hearing about the destruction of Königsberg, Renate wants her parents to tell the story of the "wertvollen Familien," and the first generation defends itself against the attack: " 'Renate, was gibt's da schon groß zu erzählen? Das verstehen die Zwillinge wahrscheinlich gar nicht...' brummte mein Großvater" (102). Mäxchen eventually complies and tells how a war widow and her children were offered escape very late in the war, while friends of the widow were not. When the widow demanded to know why, she was told that "nur die wertvollsten Familien" (103) were allowed escape. Mäxchen finishes the story with protest against his daughter; he fails to see why the story is relevant and why Renate insists on its retelling.

Another shining example of the dynamics between the first and second generations, the story can of course be understood by the third generation, the twins, who are now sixteen years old. Mäxchen wishes to not retell the story, because it brings to light attitudes that are difficult to defend. The twins take the story in and do not challenge him.

By the time the twins are this age, they have officially been taught in school about the Holocaust. In his study, Opa war kein Nazi, Harald Welzer found that many education opportunities exist for students in Germany to learn about the Holocaust, and 
that they are, in general, popular and successful (Grandpa Wasn't a Nazi 1). Freia comments, however, that the topic is handled in the same way every other school topic is handled, and concedes she failed until much later to make any connections between the past and the present:

Diese Diagramme, Daten und Fakten schienen in keinem Zusammenhang zu den Gesichtern um uns herum zu stehen, den Namen von Firmen, die wir gut kannten: Schering, Degussa, BASF, Hoechst...zu irgendeinem Politiker, der sich in die neue Zeit hinüberretten konnte. Nie kam uns in den Sinn, daß unsere Lehrer damals selbst in brennenden Häusern gesessen, auf Viehwagen geflohen, als Sechzehnjährige in den Krieg, als Kleinkinder in den Bombenkeller geschickt wurden. (Dückers 94) Only one teacher - the only one to earn the right to have a name in Dückers' narrative provokes the students to ask themselves, for example, whether they see the prejudicial treatment of the Turkish people in Berlin as a step towards the kind of hatred displayed against the Jewish people during the Hitler era.

Damningly, Dückers relates that in the Oberstufe, the higher grades in school, "wurde der Nationalsozialismus noch einmal 'durchgenommen' " and so fairly treated as to leave the impression that "alles hat zwei Seiten", that somehow previous events in history could explain Germany's slide into fascism (95). Dückers allows Freia to question how any circumstances could lead to "Lust auf Massenerschießungen" (95) and to express feeling anything but empowered to follow up with the adults in her life. Because the twins hadn't been faced with the situation, Freia claims, it was not expected that they would be able to express an opinion about what had happened, and more importantly, 
were confronted with the disempowering attack: "Na, ihr wißt ja gar nicht, was ihr damals an unserer Stelle gemacht hättet!" (95). One must question whether the upper division Holocaust education really was reduced to "Massenerschießungen." Is this Freia or Dückers who is unwilling to fully name genocide and the Nazi horrors, or does it represent an attack on the educators who have failed to name them? Surely more details than mass shootings belong to an education about the Holocaust in upper level courses. Freia is frustrated that, even though National Socialism is a repeated topic in school, critical thinking or a real Auseinandersetzung with the topic was not part of the picture; she recognized that work was her responsibility to accomplish. In coming to this conclusion, Freia echoes a further finding by Welzer, namely that "Knowledge and the assimilation of knowledge on a personal basis are two very different things" (Opa Wasn't a Nazi 1). Dückers seems to agree with Welzer's conclusion and presents a main character who sees it as her responsibility to strive for this acquisition of personal knowledge.

Some of the answers Freia seeks are in Poland, where she decides to venture after the sudden death of her Uncle Kazimierz. Kazimierz' mother was Jo's sister, representing the German side of his heritage, and his father was Polish. Both his parents died in the chaotic aftermath of the war, leaving Kazimierz orphaned. Renate stayed in touch with Kazimierz, visited him many times, and Freia knew him well. This trip comes at significant personal cost - she forces the travels on her boyfriend at the time, a sullen Wieland, who has no desire to dig around in the past and who remains emotionally unavailable throughout the trip; they argue, which they never did. True to her personality, Freia takes the trip because she has unanswered questions she cannot leave behind. 
Kazimierz had committed suicide, and no one knew why. What dawns on Freia during her investigation is that the suicide is perhaps most bothersome because it seemed out of character:

Hätte Onkel Kazimierz nicht zwanghaft Lakritze gegessen, sondern Sonaten in d-moll gehört oder Reproduktionen von Käthe-KollwitzGraphiken gesammelt, hätte keiner seinen Selbstmord so seltsam gefunden...Aber mein Onkel haßte Geständnisse, er haßte, verabscheute die Wahrheit. Er liebte das Opake, sein Lieblingsstein war der Onyx, sein Lieblingsbaum die dichte Hemlocktanne...er war stolz, er wollte nicht über die Dinge sprechen, über die alle Welt reden wollte. (Dückers 175)

How the man could arrive at such a state where suicide made sense is what Freia hopes to uncover by visiting his city and talking with people who had been close to him.

The Warsaw Freia discovers does not definitively answer the questions she has about her uncle, but the journey allows her to mourn the loss of him and to reflect on losses caused by her country's actions. Dückers produced with this interlude what would seem to be an answer to a requirement Ernestine Schlant described as missing from most previous Holocaust literature. Schlant quoted a translation of Jürgen Habermas as the introduction to her review of works by authors of the second generation: "The work of mourning is essential, not as "penance" but as an indispensable prelude to the formation of autonomous and mature identities for both nations and the individuals who comprise them" (Schlant 80). Freia describes a mournful, melancholy and morose reflection of Warsaw that sticks with the reader. 
Freia meets with people in Kazimierz' circle: "Ich hatte mit elf Leuten über Onkel Kazimierz gesprochen...hatte Orte abgeklappert, die mit seinem Leben in Verbindung standen...Meine Recherche hatte nichts ergeben, nichts zutage gefördert, was ich nicht schon zuvor gewußt hatte" (Dückers 173). She wanders the streets of Warsaw, specifically finds the Warsaw Ghetto and locates the "Umschlagplatz," that, at this point in time, has yet to be marked with any sort of monument. Freia reflects on visiting this place with her uncle who would make "saudumme" remarks: "Was für ein niedlicher Hühnerstall, dieser Platz, ich glaube, die Neonazis haben doch recht: hier haben keine 300000 Menschen drauf gepaßt!" (168). She tries, like "Tausend vor mir getan hatten" (168), to imagine people standing here in the cold on the way to their death and is shocked to find herself distracted by her boyfriend's physical appearance, here at the place of so much past suffering. She cannot reconcile the lively place she sees with what she knows the place once was: "Das Wissen, hier haben sie gestanden, hier wurden sie abgeholt, blieb für mich gänzlich abstrakt" (170). Most importantly, Freia comes to the conclusion that not being able to reconcile this means that this place is no longer a place: "Ein Denkmal ist geradezu der sichere Beweis dafür, daß hier kein Ort mehr ist. Ein Ort kann nicht gleichzeitig existieren und an derselben Stelle kommentiert werden" (170).

Trying to imagine what the city was like - what it smelled like, sounded like, looked like - in the 1940s, Freia realizes the Nazi goal of destruction of the east succeeded here at this place and: "auf dem Fleck Erde stehend, der einmal das Warschauer Ghetto gewesen war, wurde mir vielleicht ansatzweise die Dimension der Auslöschung seiner früheren Bewohner bewußt, die weit über ihre physische Vernichtung hinausging: Kein sinnlicher Eindruck vermittelte noch ihre Existenz" (171). 
Nothing was left to experience, and this, ironically, was the true sense Freia established for herself for the first time in the life. In other words, a presence was truly established through the absence.

At another place in Warsaw, die "wiederaufgebaute Altstadt am westlichen Weichselufer" (171), another phenomena had taken place, although the results - ein Unbehagen - for Freia are similar. Freia claims to understand that the Polish people wanted to turn back time with their Warschauer Tempo and rebuild the old city center, rebuild it in fact completely and perfectly. The result of that, Freia muses, is simply to draw attention to what the Germans did first and the Polish people did second, leaving only pain: "...das doppelte Ungeschehen-Machen, erst der Deutschen, dann der Polen...glänzte für mich der Schmerz" (172). She decides, however, in the end, the Polish people will be in the right: this perfectly rebuilt Altstadt, in a few hundred years, will truly be the Altstadt and the Germans' attempted annihilation will only stand as a date in a history book. Disquietingly, Freia adds the qualifier "Vielleicht" (172).

Not wanting to admit that, although she experiences a Beklommenheit that won't go away, Freia actually felt nothing. She does not want to share this sense with Wieland, the one who insisted nothing would come of her attempts to understand. Freia cannot live with that; she has to engage with the confrontation, come what may.

After buying licorice and remembering that both her mother and her Uncle Kazimierz shared the tick of obsessively sucking licorice, Freia cries. In fact, she cannot stop crying. She notices her gums burning from the salty licorice, and it occurs to her, "Man ist so alleine, wenn man ißt" (175). But she feels a shared experience with her uncle who sucked on thousands of pieces of licorice and concludes that she can have no 
idea what darkness Kazimierz lived with - it must have been some nexus of the personal and the collective born out of the disastrous times he lived through.

She travels home on the train, along the border between Germany and Poland, and stares out the window "wo wie ein düsteres Heer all die Tannen an mir vorbeiflogen, die Deutschland und Polen voneinander trennen und miteinander verbinden" (176). Freia mourns her personal loss - her uncle, sad, alone and suicidal; and, a collective or societal loss - destruction, devastation and an abiding separation of neighboring countries.

Though Freia has unanswered questions well into adulthood - she is a grown woman about to give birth to her first child when she finally satisfies her curiosity, she searches for answers, according to her ability and maturity level, her whole life. While listening to another set of Jo's "zurechtgelegte Sätze," this time a detailed description about her escape from Gotenhafen in January 1945, Freia picks at a detail she thinks is missing. The critical importance of the detail becomes clear only later, after Freia had heard the same story from Jo over and over again.

Jo's family ended up in Gotenhafen, because her father had sold his MarzipanSpezialitätengeschäft in Königsberg "als er den höchsten Preis dafür verlangen konnte, weil es der Wirtschaft ja bekanntlich sehr gut ging" (123) and changed careers to join the merchant navy. Jo met Mäxchen, a trained civil engineer employed by the Nazis, in Gotenhafen. Renate uncharacteristically jumps in to remind her mother that Gotenhafen used to be, and now is again, Gdynia (124). Jo loses her temper and asks her daughter if it is really necessary, given that she had to give up her homeland, that she give up everything else, too. Renate was silent, "denn sie kannte diese Sätze nur zu gut" (124). Mäxchen jumps in to describe how he was part of the Rußlandfeldzug and that "Alles lief 
wie am Schnürchen bis zum Wintereinbruch" (125), words the children have heard multiple times. Together, Jo and Mäxchen form a coordinated front against Renate and her attacks.

"Tausende von Flüchtlingen" arrived with horrible stories of Russian attacks in East Prussia. As war had finally reached Gotenhafen, Jo relates how they decided they would have to flee: "durch unsere, na, ich will nicht sagen: guten Verbindungen, aber eben einfach: Verbindungen zur Partei hatten wir noch verhältnismäßig viele Informationen über die wirkliche Kriegssituation" (126). Daring to ask after these "connections to the Party," Freia receives the answer: " 'Freia, wir waren keine Nazis. Jede gewalttätige Ausschreitung haben wir abgelehnt. Grob, furchtbar fanden wir das. Vulgär. Diese Horden, die da herumzogen. Widerlich. Dieser Krach. Unser Umfeld war treudeutsch, aber nicht nazideutsch. Das war ein großer Unterschied, müßt ihr wissen' " (126). Renate responds to this by stepping out to the restroom; the moment passes, unquestioned.

Jo continues the narrative of how they fled as the fighting approached - how they decided what to try to take with them, what to dress five year-old Renate in so she would not freeze, what to try to pack in three big sea chests that Mäxchen rounded up through "guten Kontakte als Bauingenieur zur Marine" (133), how to separate from Mäxchen who had to stay behind and defend the port. A huge jump in the narrative occurs, and Jo describes arriving in Minden where they were seen as "die absoluten Niemands" (134). Renate jumps in to question how the Germans can be excused for rejecting their own; in general, Renate impresses with her detailed knowledge of military strategy, facts and stories. Freia claims she acquired these in an attempt to make up for the inadequacy of 
being a child during the war and having to continually hear the accusation from her mother: " 'Was weißt du schon, du warst doch damals ein Kind!' " (128). But her knowledge cannot be accepted by Jo or Mäxchen. They have their story and will not deviate from the details.

Mäxchen works to fill in the gaps Jo left out and describes how they decided where Jo, her sister Lena, and Renate would go. They heard from neighbors about a minesweeper that was being used to transport civilian refugees, because "Die großen Schiffe wie die 'Wilhelm Gustloff ' waren....noch nicht für den Flüchtlingstransport freigegeben" (136). Because of the number of refugees in the city though, the Gustloff was eventually made ready. Freia asks how Jo and Renate came to be allowed on the minesweeper instead of the Gustloff. Instead of an answer, Mäxchen explains how much he knew about how poorly the Gustloff was prepared for its final voyage, loaded down with over 7000 passengers (141), but Jo answers that Mäxchen knew the minesweeper would be the better choice. They survived their flight, unlike the passengers of the Gustloff, which was sunk by Russian torpedo fire.

As Jo ages, she rehashes this story ever more frequently. Freia visits Jo, as Mäxchen lies dying in the hospital; Jo is failing physically and mentally, and Freia asks "Wie lange wird sie noch bei uns sein?" (212). Because Freia does not have the answers she seeks, she turns to drastic measures to uncover what her grandmother has not yet revealed: she pretends to be Jo's sister, Lena. In her confused state of mind, Jo does not recognize Freia and reacts to "Lena's" probing questions, but goes in and out of recognition. Freia knows there is a secret buried in this story, she is only unsure of the exact details. In a moment of mental clarity, Jo tells Freia how closely they came to 
boarding the Gustloff instead of the minesweeper - they arrived too late at the dock and the doors were closed. They waited and waited, but there was nothing they could do: " 'Plötzlich nützte alles nichts mehr...daß wir in der Partei waren...nützte gar nichts...' " (219). Freia is astounded - she reflects on how often Jo had only claimed to have "connections" to the party, how she had always avoided directly answering the question or answered with a mumbled "nein, nein." Freia wonders what other advantages Jo had gained, given her party membership, and "was sie alles wußte, was ich nicht wußte. Was sie vergessen hatte und an was sie sich sehr wohl erinnern würde" (219). Knowing her grandmother harbors important secrets, and most tellingly, being a member of the third generation, Freia is keenly aware that "Der Satz 'ich erinnere mich nicht' könnte zur Ausrede werden..." (219). This recognition weighs heavy on Freia and she can't shut her mind off to sleep well while at her grandmother's house. She fears sinking "zurück in die Geschichte, dorthin, wo ich herkam" (220). Even though the truth is hard to accept, Freia cannot be satisfied with half stories.

Realizing time is running out - the Tätergeneration is on the verge of dying out, Freia visits her grandmother again; Mäxchen is dead. Freia starts right in and tries to get her grandmother talking. She wonders if she is going to have to trick her grandmother again, but this time Jo opened right up. In answer to Freia's insistent question about how they came to be able to board the minesweeper, Jo relates that little Renate, in front of the man who would decide who made it on board and who not, mentioned damning words about the other mother and son who desperately wanted on board: " 'Da rief Natilein plötzlich...'Die ham gar nich mehr den Gruß gemacht. Schon ganz lange nicht mehr.' Und Nati streckte ihren dünnen kleinen Arm sehr gerade nach vorn...Renätchen hat uns das 
Leben gerettet...so war das' " (249). This detail had never been mentioned before, and Jo says she knows that Renate does not want to talk about the story. That Renate knows this was the sequence of events is clear to the reader; this was the secret, and the guilt, she had carried through the years. Innocent though she was, at five years old, Renate was the one responsible for the fact that she, her mother and aunt were chosen to board the minesweeper, while others went to their deaths on the Gustloff.

Freia finally has uncovered the secret she knew had been buried deep in her family. She worries the shock will make her lose her child, and she wrestles with how guilty she should feel about being alive and able to pass on the gift of life, while others without her family's strange luck cannot. All of it is almost too overwhelming. She recognizes that the being in her, however, is on her own path now, dependent on her but also separate from her. Freia pays a tender and knowing homage to her city, which she will experience with her child:

Ich würde mit meinem Kind zur Schule durch die Stadt gehen, die Stadt würde mit meinem Kind zu mir zurückkommen, zurückschlagen, die Gedächtniskirche, die Einschußlöcher an den Häusern in Friedrichshain, die ungebrochene Würde der jüdischen Synagoge an der Oranienburger Straße, die eine Schande für diese Stadt, immer noch oder schon wieder bewacht werden mußte...es gab kein Entrinnen, ich mußte mich stellen, der Zukunft und der Geschichte, die, in der Neugierde meines Kindes, persönliches und kollektives Erleben untrennbar vermischen würde. (255)

Freia goes into the future with knowledge. This is what she needed and wanted. Although she is aware of the weight of the burden, she sees no other way to face the future than to 
carry it. What she has learned won't be something she never thinks of again, but something that informs her and her child's life.

Unfortunately, some truths still lie buried, even after the huge revelation about Renate's actions. Following the examples of the Väterliteratur era, Dückers employs the tactic of uncovering these secrets after the death of a member of the Tätergeneration. Both grandparents have died, and the legion of women shows up to "die Beerdigung und die Wohnungsauflösung" (256). As a story about mothers and daughters, "Die Männer glänzten durch Abwesenheit" (256). Unfortunately, Freia was afraid the entire time; about what, exactly, is not revealed. One can imagine she is worried about what she will uncover.

Freia's grandparents do not disappoint. In a bag over stuffed with dusty garlands of plastic flowers, Freia finds a box covered with gold wrapping paper. In the box are seven post cards from the Führer; three pictures of the Nazi aviator pilot Hanna Reitsch, the woman Freia knows trained young volunteers for suicide missions in Hitler's army (57); a bike reflector decorated with the swastika; photographs of an event where they personally saw Hitler; a book entitled Menschenkenntnis und Charakterkunde. Zur Erkennung und Beurteling der Kopf- und Gesichts-Formen written by Emil Peters; and, drafts of letters Jo had written congratulating Göring on the birth of his child.

Additionally, a map memorializing the progress of Hitler's army on the Eastern front wrapped up a copy of Mein Kampf. Freia reflects about this book: "Sie hatten es nicht nur besessen, sondern auch noch Anfang 45 vielen anderen Büchern vorgezogen und auf die Flucht mitgenommen" (262). Freia thinks back to all of the comments about Hitler and the Nazi era she thought her grandparents had made ironically. She remembers comments 
they made that were right on the edge of being indefensible. She reflects on how weak and unthreatening they had grown in their old age. She claims she never thought of them as Nazis. She cannot unite her grandparents, with all the connotation the word brings along with it, with the monsters that were the Nazis.

Experiencing this disconnect was found by Harald Welzer to be quite common. Welzer states that images of the beloved relative, based on "socialization and time spent together" are the images that stick with children and grandchildren. The "family's memory" (Welzer, Opa Wasn't a Nazi, 7) simply does not record stories of atrocities. Dückers' novel contains no stories of atrocities; she does not overtly implicate Jo and Mäxchen in anything other than being on board with some Nazi ideals and holding onto Nazi memorabilia. No reason exists to think that Renate or Freia heard stories they simply did not record. Still, Freia is guilty of never putting two and two together. She literally has to hold evidence in her hands to accept that her grandparents were Nazis.

One could speculate that Freia is more bothered by the fact that all these items and what they represent were never destroyed. She comments: "Der Gedanke war mir unheimlich, daß die Kästen hier, fünfzig Jahre lang, von niemandem angerührt, ein friedliches Dasein gefristet hatten" (265). These undisturbed items represent, possibly, attitudes and opinions that remain undisturbed. This fact could be something that Freia simply could not confront while her grandparents still lived.

Renate and Freia sit together thinking about what it means to find all of these items, fifty years on. An old coping mechanism slips in: mother and daughter do not speak. Freia reproaches herself frightfully afterwards: "Dafür, in diesen Augenblicken darauf vertraut zu haben, daß die Stille beredeter sein würde als Worte" (265). Not 
knowing what to say to her mother, Freia is also in shock at how she has to now amend her impression of her grandparents. When the moment arrives to confront the hard realizations, however, even someone as strong and committed as Freia buckles under the pressure. The reader cannot help but feel that a moment of reconciliation and enlightenment would be very helpful to these two women; sadly, the moment is missed. In contrast to Freia, Renate cannot live any more with the guilt of the past. After she and Freia take a visit to Gdynia and the harbor where the story all started, and after Renate sees the birth of her granddaughter, she commits suicide. She threw everything away, straightened everything up, and died in her bed. One senses that, even though she carried secrets her whole life, the fact that others now knew the details was too much for her.

Renate, full of accusations and aware of her parents' identification with the Nazis, never helped her daughter process the information or work through the conflicting images her parents presented. While she never made excuses for her parents, Renate never renounced them either. Her act of suicide is a hopeless act; everything was insurmountable, and the reader recalls how, on the evening Freia discovered her secret, Renate spoke of everything only ending in destruction and darkness: "Und immer wieder rinnt und tropft alles herab, glänzt auf, um stumpf und unsichtbar zu werden. Immer wieder am Ende die Nacht!" (253).

Renate, unlike some of those of the second generation recounted by Welzer, never "mediated" or "changed" or "opened to interpretation" (Grandpa Wasn't a Nazi 13) events or experiences related to her by her parents. Additionally, she does not let her parents off the hook or see them as "victims of the conspiracy" that was National Socialism either 
(Schneider in Schlant 84). If anything, Renate stays true to the accusing and combative reactions of the second generation. Indeed, Jo comments on this when asked by her daughter why she thought a child of five years would be ready to tattle on another, if not for having seen the behavior from her elders. Jo flees into the excuse, " ' Ich erinnere mich nicht!' " (252), and comments that Freia, unlike Renate, had never accused her of anything. While Freia had succeeded in approaching her grandmother in a nonconfronting manner, Renate never could. Dückers believes this is a key difference in how the generations approach the topic of the past (Der nüchterne Blick der Enkel) and skillfully works this trait into the narrative.

Renate cares for her parents to the end. Whether she does so as an expression of loyalty or love for her parents, or, what is most likely, a combination of both, is never addressed in the narrative. What comes across most clearly is that Renate tried to shoulder the burden of her past to the best of her ability. She is truly the tragic figure of the narrative, caught between the first generation - those who survived by defending their actions, and the third generation - those who can view the past from the distance of time and space.

Freia also closes the chapter on the cloud she has been searching for. While in Gdynia with Renate, she finally spots and photographs it. One senses that for Freia, the cloud represents a release. Knowing provides a certain freedom and a future that is informed and, while not free of the past, not so burdened as to be a handicap like her mother lived with her whole life. Again, contrary to findings in Welzer's study, Freia now has a deep knowledge of history, but does not feel the need to protect her family story from the truth (Grandpa Wasn't a Nazi 16). Dückers produces a work that advocates for 
knowledge and investigation into the past; she playfully wraps up her narrative with Freia's desire to memorialize knowledge for posterity.

Paul shares this sentiment. Freia visits Paul in Paris when Aino, her daughter, is two and after Renate had been dead over a year. Paul is suffering from the burden of his family's past - it is a very personal suffering he describes as a "komische Hintergrundstrahlung" (Dückers 317), reminiscent of Claudia Brunner's Phantomschmerzen. He sees the past everywhere and begs Freia to help him capture it in a story, so that it can turn into a piece of art that is outside of his head, concrete and separate, but certainly not buried or made benign. The twins decide they will write Freia's story, in which Paul appears, and name the story Himmelskörper. Paul and Freia offer no explanation as to the title; this is left for the reader to interpret.

Dückers' novel is a smart and rich portrayal of the tasks facing the third generation. Very much entitled to a life free of guilt for actions of prior generations, the grandchildren nonetheless are a product of them. As such, they have a responsibility to be educated and informed about the history and aware of its impacts on their lives. The fictional Freia experienced the impacts of silence and avoidance very directly in the tragedy of her mother, and thus felt a compulsion to uncover the secrets that had been so damaging. The story pointed to a hopeful future for the next generations, one that is achieved by looking soberly at the facts and being enlightened and informed. 


\section{Chapter 3 - Die Dritten in Literature and Film \\ Karlebachs Vermächtnis}

Journalist and author Uwe von Seltmann, born in 1964 in Germany, states that the purpose of his work is to bring the continuity of the past to light (Uwe von Seltmann). In two of his works, Schweigen die Täter, reden die Enkel, the diary he co-wrote with Claudia Brunner in 2003, and his earlier novel, Karlebachs Vermächtnis, published in 2000, von Seltmann illustrates his opinion: "dass es keinen Schlussstrich unter die NSZeit geben darf, ja gar nicht geben kann - die vielfach bemühte 'Stunde Null' war und ist eine Illusion" (Brunner and von Seltmann 14). A third generation author, von Seltmann writes to show how the past influences contemporary, everyday life.

The novel, Karlebachs Vermächtnis is about the consequences of past silence, avoidance, and the failure to hold individuals accountable for their crimes, even crimes reaching back decades. Whereas Tanja Dückers focused inward for hidden secrets, and made uncovering them a personal quest along the way to maturity, von Seltmann looks outward into the power structures of society to find the past's shadows. Karlebachs Vermächtnis, a narrative much more for the common man than Himmelskörper, is uncomplicated, instructive, broad in its sweep, and assumes no prior knowledge of the Nazi era. With his entertaining novel, the author reminds us that history is not just something for the history books.

The main character, Ulrich Weißmann, is not especially bothered by secrets, family or otherwise, until he is almost thirty years old; indeed, the university student is surprised to learn that a building in his village called das Judenhaus would have a history worth talking about. A character who would appeal to today's youth, Ulrich drives an old 
Renault, fire red in color and named "Florian." To help finance his student life, which is drawing long, he works part-time at the town newspaper, the Lokalpost. He likes to stay up all night drinking with his buddy, Andi, and is proud of himself when he goes from being asleep to driving in his car in less than six minutes. He is endearing, in his haphazard way, and some of the experiences he relates are lighthearted, earning the novel's description as unterhaltsam. Ulrich grows up through the course of events, learns of his family legacy, and charts his personal path forward. He is an upper-middle class, modern, educated German with resources and a strong sense of his own abilities. With no living grandfathers - both "sind im Krieg geblieben" (von Seltmann 17), Ulrich adopts "Opa Bernhard," a man of almost 90 years old who had earned Ulrich's trust early in the boy's life. Sharing the story of many, Ulrich and his brother know nothing of their grandfathers but two old pictures. One surviving grandmother cried whenever questions were posed and the boys' father never spoke about his parents. The children learned early to leave the topic: "Unsere Fragen wurden mit Floskeln abgetan und blieben unbeantwortet." (17); this bothered Ulrich no further. Opa Bernhard, so named by the whole village, is a member of the war generation and he and Ulrich share a close relationship.

While enjoying a visit from Ulrich, who is home for a weekend from the university, Opa Bernhard reports that he feels his time on earth is limited. Although Opa Bernhard has shared many stories with Ulrich, over and over again, he has one last story he must tell: "die Geschichte vom Judenhaus" (14). Ulrich is shocked; Opa Bernhard had never mentioned the Judenhaus before. To further provide structure to the narrative, Opa Bernhard dies, his head resting on Ulrich's shoulder, before he tells the story. Bernhard 
had managed to scratch out a vague note to Ulrich, the contents of which are hard to decipher: "Dort ist etwas Schreckliches passiert. Ich weiß davon, aber war zu feige...zwei Männer unseres Dorfes...Unrecht Gut darf nicht gedeihen...Bitte..., damit ich in Frieden sterben kann" (20). To further spur Ulrich in the right direction, Bernhard leaves him the Karlebach family bible. Ulrich deciphers a handwritten note to learn how Bernhard came to be in possession of the bible: " 'Lieber Bernhard', las ich dort, 'zu deinem 50.

Geburtstag überreiche ich dir unsere Familienbibel. Ich bin der letzte Überlebende unserer Familie. Mit mir stirbt sie endgültig aus. Du hast mir das Leben gerettet, dafür danke ich dir. Schlomo Karlebach, New York, 10. Mai 1959' " (68). Lastly, Ulrich learns specifically of two letters from Karlebach to Bernhard, one from 1973, and one posted from Jerusalem right at the time of Bernhard's death. Bernhard and Karlebach had been in correspondence over the years, and more importantly, Karlebach was still alive. Holding the inherited bible in his hands, Ulrich assumes the story of the Judenhaus must involve Schlomo Karlebach. He decides he owes it to his old, dear Opa Bernhard to respect his request and reveal the secrets taken to the grave.

That the Judenhaus had stood in the village until he was seven years old, inhabited by an old woman he thought was a witch, is really all Ulrich knows. Now that he needs information and the Judenhaus has come on his radar, he wonders, "Wer von den Älteren aus unserem Dorf würde sein Schweigen brechen?" (68). In a further nod to secrets and avoidance from the past, Ulrich remembers his first grade teacher had reported that the Judenhaus was a place of shame and would be torn down. More was not said. 
By turning to two other villagers who might have answers, Ulrich interviews the remaining possible eye-witnesses to history, Onkel Alfred and Onkel Kurt, neither relations of Ulrich. Onkel Alfred reports he first came to the village after his imprisonment in 1946, as his parents' home lay "in Schutt und Asche" (24). He got a job with old "Fabrikant Frick" who could no longer employ "foreign workers" and knows that the supposed witch who lived in the Judenhaus at that time was "die Tante vom Oberkirchenrat Knecht" (23). Ulrich asks the logical question - who lived in the house before the war, and as Onkel Alfred formulates the painfully obvious answer, " ' Doch, warte mal...So langsam entsinne ich mich. Juden haben dort gewohnt. Aber die sind alle tot. Im KZ umbegracht.' " (24), the reader is struck by how unaffected both characters really seem to be by the history. Neither Alfred nor Ulrich see the irony of the name Judenhaus, or seem especially affected by the fact that this name had stuck in popular consciousness, or struck by the events the name clearly referred to. The reader understands the story will draw some much-needed attention to this accepted platitude.

Onkel Kurt introduces Ulrich to the fact that current members of the community had relatives who were Nazis. Ulrich sounds completely naive when he asks Kurt: " ' Gab es denn hier gar keinen Widerstand? ' " (77). Kurt laughs and reports that old Pietsch, the father of their current representative to the Landtag, young Pietsch, was the one responsible for deporting all the Jewish people from the village. Old Pietsch had also been in power only a week when he ordered Kurt interned in Dachau: " 'Weil ich Sozialdemokrant und Pazifist war und mich weigerte, die Hakenkreuzfahne aus dem Fenster zu hängen' " (77). After a year, he was given a choice to go to the front or stay in 
the "KZ." His answer: " ' ich bin kein Held, also bin ich in den Krieg gezogen. Als überzeugter Pazifist' " (77).

Kurt tells Ulrich that old Pietsch's son, young Pietsch, ordered the Judenhaus torn down, even though other villagers wanted to keep it as a memorial site. He also validates Ulrich's impressions about his dear friend Bernhard: " ' Bernhard galt als Judenfreund. Er unterstützte die Juden, wo er nur konnte. Auch noch, als es wirklich gefährlich wurde. Das weiß ich aber bloß vom Hörensagen, weil ich ja weg war. Er soll sogar eine Zeit lang einen Juden bei sich versteckt haben...' " (78). Bernhard was a carpenter, Onkel Kurt reported - he worked for "Fabrikanten Frick in der Kriegsproduktion" (78) - and that surely saved his life. Ulrich wants to know if Kurt knows anything about the Jewish person Berhard supposedly hid, but Kurt claims no knowledge. While Kurt and Ulrich are talking, another villager, Flurschütz Röther, yells " ' Heil! Heil! ' " (79) and, even though Ulrich runs up to him to find out why he is yelling, the reader gets the distinct impression this kind of event has happened before and is overcome by a sense of foreboding. Ulrich has gathered the information he could from old members of the village, representatives of the first generation, but is clear there is more to uncover.

With Karlebachs Vermächtnis, von Seltmann has spun the perfect generational novel, albeit with a nasty twist. Generally, the second generation is accused of avoiding dealing with the past and of perpetuating silence and ignorance for future generations. If one is generous, the second generation can be let off the hook by acknowledging that holding parents to account is, at best, difficult. Ernestine Schlant pointed out that the second generation had found itself in a "schizophrenic situation" (Schlant 83); they had trouble unifying the love they felt for their parents with the thought that the parents could 
also be evil perpetrators of crime. The conflict was simply easiest avoided. The portrayal of the second generation in Karlebachs Vermächtnis is itself schizophrenic.

Uncomplicated and one-sided characters are either completely innocent, or completely guilty.

Ulrich's parents, no 68ers in the slightest, are simply let off the hook. They are barely even characters in his narrative, but when they do show up, their only contribution is to feed him; worry about what danger he is in; cajole him to see to his responsibilities; and, to act as answering machine or hotel service. Ulrich learns through the course of his investigation that his grandfather was a horrible Nazi. Not only does Ulrich not share the information with his father, but how his father might have reacted to the disturbing revelations is completely missing. Von Seltmann portrays an empty, uninterested, uninformed and one-sided generation in the characters of his mother and father.

On the exact opposite side of the spectrum, all other members of the second generation in von Seltmann's novel are corrupt, and some cross the line into criminal. While trying to figure out who the guilty individuals Bernhard mentions might be, Ulrich realizes the events he refers to are probably not from the war. Sardonically, he is able to draw this conclusion by reflecting on the fact that the whole village was implicated in the removal of the Jewish villagers, not just two men. He gathers this from a conversation with Onkel Alfred, while wondering how he could be so ignorant as to the facts of the Judenhaus. Onkel Alfred tells Ulrich: " 'Das ist doch klar, Ulrich', sagte Onkel Alfred. 'Es hat doch hier jeder ein schlechtes Gewissen gehabt. Meine Schwägerin sagt, das ganze Dorf hat zugesehen, als die Juden abgeholt wurden. Viele haben geklatscht. Und der Pietsch, der Vater von Bertold Pietsch, der war damals Ortsgruppenleiter und hat die 
Aktion geleitet. Er soll ein Schild aufgestellt haben, auf dem geschrieben stand: Dieser Ort ist judenrein" (von Seltmann 43). Three Jewish families had found short-term refuge in the Judenhaus; the Karlebachs, who were jewelers; the Rosenthals, who were cattle dealers; and, the Grünsteins, who were shop owners. While forcing the Jews out of the village is certainly something horrible, Ulrich knows Bernhard refers to other crimes. Digging around in the past ruffles feathers. Before he knows what he is up against, Ulrich receives very welcome attention from a beautiful young historian, Simona Zorbas. She warns him not to cross paths with "Fabrikant Frick" or Pietsch, who is being talked about as the next economics minister. Ulrich dismisses her concerns. He thinks again, however, after attending a New Year's Eve party with Simona - a "Schickifete" (131). Ulrich overhears that Simona has had some kind of relationship with both Frick and Pietsch. Disgusted, he cuts his losses and leaves, only to run out and find his car has mysteriously rolled down the hill to end up in a heap of destroyed metal. He calls his friend from the newspaper, Helmut, to come pick him up, relates the story, and Helmut decides to beat the bushes a bit. They slip a provocative story into the morning newspaper, "eine haarsträubende Geschichte, dass mich die Strohmänner von einigen wichtigen Leuten verfolgten, dass ich in Lebensgefahr sei, dass ich bald zum Recherchieren ins Ausland reisen müsse usw" (139). No names are mentioned, and not a word about the Judenhaus is uttered; but, all of a sudden, the town buzzes with activity.

The newspaper boss, who had not approved printing the story, is furious. He has taken calls from everyone: "Den ganzen Morgen klingelt unaufhörlich das Telefon. Die Agenturen, das Fernsehen, die Polizei, Pietsch, Frick..." (144). He demands Ulrich and Helmut recant the story and cannot see that they have clearly hit on something, given the 
outcry from people who were not even named in the article. Ulrich leaves his boss' office, chastised and threatened, with the proverbial tail between his legs, to meet with his studies advisor, Oberkirchenrat Knecht, who simply threatens him: " ' Lass die Geschichte mit dem Judenhaus, dann hast du nichts zu befürchten!' " (147). Ulrich seeks out Onkel Kurt and Onkel Alfred for advice. In an about-face, both refuse to see him or to answer any more questions. Ulrich is shocked, but now starts to gather he is truly onto something. He doubts himself, however: "Ich würde die Vergangenheit ruhen lassen. Die Erfüllung meines Gelübdes machte Opa Bernhard nicht mehr lebendig. Die Sache war oberfaul, sie stank zum Himmel, aber ich war kein Held und würde niemals einer werden. Ich gab auf" (150). Ruffled feathers, however, are a journalist's dream, and his boss at the newspaper rethinks his position. He decides Ulrich must go to Jerusalem to gather facts from Schlomo Karlebach, who holds the key to the story of the Judenhaus that has so many tongues wagging.

Schlomo Karlebach eventually reveals to Ulrich a story that implicates every official in town, all members of the second generation: Bernhard's son, who "hatte überhaupt nichts von seinem Vater, keine Wärme, keine Güte" (327) and the Oberkirchenrat Knecht had collaborated to falsify ownership of the land rightly owned by Karlebach, the land the Judenhaus had stood on; the local factory owner Frick profited from that theft; Pietsch knew the swindle was occurring and had turned a blind eye. To add insult to injury, Bernhard's son and Knecht had stolen jewels that had been buried on Karlebach's property. These crimes had been committed in 1974, and all of the responsible people were still in positions of power. In one sweep, Ulrich finds criminals in the current halls of government, the church, and industry. 
Ulrich is armed with facts from Schlomo Karlebach, but little proof. He dreams of exposing the criminals and writes a story for the newspaper. Unfortunately, he awakes to learn that the criminals had intimidated the newspaper editor. No story would be forthcoming. The crimes from the past, not to mention crimes that were not accounted for from the Nazi era, would be left unpunished, and the criminals would remain to continue to wield power.

Another theme that unfolds in Karlebachs Vermächtnis, in contrast to Himmelskörper, is the suffering of Jewish individuals and the crimes committed against them. Schlomo Karlebach spends many hours with Ulrich in a café in Jerusalem, relating his personal story and detailing the fate of the Jewish people in Germany. The years disappear as he spins his tale, and Ulrich and the reader are carried away.

Karlebach describes how, before 1933, the three Jewish families in the village led a normal existence: "im Großen und Ganzen ließ man sie in Frieden leben. Sie waren ja, was man assimilierte Juden nannte" (244). Step by step, Karlebach runs through the history for Ulrich: how, for example, in April 1933, the Nazis called for a boycott of Jewish stores and the Iron Cross that granddad Karlebach had earned in World War One became irrelevant; how, after passage of the "Gesetz zur Wiederherstellung des Berufsbeamtentums" (249), Schlomo's father lost his job in January 1934; how, shortly after that, the city cancelled the family's rental agreement for their apartment; and how, finally, on "9. November 1941...überreichte uns Pietsch persönlich den Deportationsbefehl" (281). At one point, while listening to the agonizing details, Ulrich asks a question many have surely asked: " ' Warum sind Sie nicht ausgewandert?' " (250). The answer is heartbreaking: " 'Das ging nicht. Großvater Karlebach hatte beschlossen: 
Unsere Familie bleibt in Deutschland. Die Karlebachs warten ab, bis der Spuk vorüber ist und alles wieder so wird wie früher. Und was Großvater Karlebach, der unbestrittene Patriarch, bestimmte, das war Gesetz. Die Familie gehorchte' " (250). Karlebach eventually lists each family member's name for Ulrich (281). The page in the book is visually disturbing, and von Seltmann's tactic is effective: in a small way, the unimaginable number "six million" gains some meaning.

Unfortunately, Karlebach holds one fact close to his chest until the bitter end, and the fact is serious. He has gained Ulrich's trust through their extensive time together and invites Ulrich to celebrate Sabbath dinner at his home, which Ulrich accepts. After dinner, Karlebach tells Ulrich that he survived the Third Reich by serving a very cruel SS man, and continues: "Plötzlich hob Karlebach den Kopf und schaute mich mit traurigen Augen an. 'Der SS-Mann', sagte er mit belegter Stimme, 'trug Ihren Namen. Sie sind ihm wie aus dem Gesicht geschnitten' " (311). Whether Ulrich had ever thought this possible, indeed whether he had ever reflected on his grandfather's past, is not part of von Seltmann's narrative. This shocking fact appears to blindside Ulrich.

Dealing with complicated emotions in the face of the facts of history is, however, part of von Seltmann's narrative. He attributes Karlebach with an intense desire for revenge that he takes out on two people, old Pietsch and a family member who fled to the United States before the war and refused to lift a finger to help those remaining in Germany when the situation became so dire. Karlebach freely admits he hounded old Pietsch until the man committed suicide:

' Ich habe mich an ihm gerächt...Ich habe ihm keine Ruhe gelassen. Ich habe ihm zehn Jahre lang jede Woche mindestens zwei Karten geschickt. 
Manchmal habe ich ihm einen Bibelvers geschrieben, zum Beispiel Die Rache ist mein, spricht der Herr oder Wer meinen Augapfel antastet, der soll elendlich zugrunde gehen. Oder ich habe ihm geschrieben, dass sich für jeden Juden, den er vertrieben hat, tausend andere an ihm rächen werden...Und...dass es überall Juden gibt, die nicht vergessen werden, was dieser kleine, unbedeutende Nazi, dieser unwichtige Ortsgruppenleiter eines kleinen, unwichtigen Dorfes, was dieser August Pietsch anderen Juden angetan hat, nur weil er einmal für kurze Zeit am Tisch der Mächtigen gesessen hat. Das...', sagte er merklich leiser, 'hat Pietsch zermürbt.' (228)

He also admits the family member begged Karlebach for forgiveness, which Karlebach withheld, and the man committed suicide. Karlebach lived for decades, self-described as "mutterseelenallein, verbittert, hasserfüllt" (318).

Living only with these emotions had, however, provided Karlebach with no closure. When Ulrich showed up in Jerusalem, asking questions about the Judenhaus, all the pain resurfaced: "aber dann erschienen Sie und erinnerten mich an Ihren Großvater. Die Schrecken der KZ-Zeit wurden dadurch wieder lebendig. Nächtelang konnte ich kaum schlafen. Ich hatte fürchterliche Alpträume und bekam Herzbeschwerden" (321). Karlebach, with the help of friends in Jerusalem, began the slow process of reflecting on the past. He eventually visited his relative's grave, laid a stone "nach Sitte der Juden" (321), and found a measure of peace. More importantly, he can share what he has learned with Ulrich and help him begin the process of digesting the past. 
Ulrich has to process that his relative was one of those partially responsible for "die Schrecken der KZ-Zeit." He claims he would have understood "Wenn Karlebach mich hinausgeworfen hätte, wenn er mich geschlagen hätte, wenn er sich an mir gerächt hätte" (316). But, Karlebach did none of that. Instead, "Er legte seinen Arm um meine Schulter und tröstete mich. Schlomo Karlebach, dessen Familie von den Nazis ausgelöscht wurde, tröstet den Enkel eines grausamen SS-Mannes" (316). Ulrich tries to picture his grandfather: "Ich fragte mich, ob mein SS-Großvater auch zu so etwas wie Liebe fähig war. Wie war er gestorben? Hatte er bis zuletzt für das Dritte Reich gekämpft und einen heldenhaften Tod im Kampf gegen ein paar armselige und verhungerte Häftlinge gefunden? Oder war er in seinen Depressionen versunken? Hatte er sich selbst gerichtet?" (317). Ulrich does not have the answers to these questions. In continuing to talk with Karlebach though, and in not being rejected by him, he can learn to live with the knowledge of the past.

Far removed from the stereotypical Jewish characters Ernestine Schlant criticized earlier, or the German characters who could not acknowledge the crimes of the past, Karlebach and Ulrich show a hopeful way forward and are good representations of characters created by third generation authors. They seek to uncover and live with the truth, partly because they see the damaging legacies caused by not doing so: living with impunity on the one hand, and harboring deep anger and resentment at the wrongs one suffered on the other are the examples von Seltmann portrays in his novel. Only someone with sufficient distance to the events could write a novel that dealt so honestly with the truth from both sides. 
In reflecting on his novel for the diary, Schweigen die Täter, reden die Enkel he co-authored with Claudia Brunner, von Seltmann admits that he had felt guilty for twenty years, ever since the American television series "Holocaust" aired on West German television, and in front of which "die ganze Familie heulend vor dem Fernseher kauerte" (Brunner and von Seltmann 99). He had felt guilty and responsible for the acts of his grandfather, Lothar von Seltmann, although his guilt was vague and not based on specifics until after his novel had been written. In other words, the grandfather in the novel was truly fictional, but hinted at the work von Seltmann would do after its writing.

In meeting with a historian, Bertrand Perz, who provided details about von Seltmann's grandfather, the author finally came to acknowledge that his fictional character was close to the truth (Brunner and von Seltmann 118). The historian had proof that von Seltmann's grandfather had been present at the liquidation of the Warsaw Ghetto, which resulted in the deaths of 56,065 Jewish people (124). Having agreed to meet with the historian in the hopes that his worst fears would be dispelled and that a photograph of his grandfather showing a "durchaus sympathischer Mensch" (119) would be the image that prevailed, von Seltmann had to admit this was not the case.

Von Seltmann also reflects on how his various relatives had, over time, tried to deal with wanting to know about this troublesome family member. One aunt in particular shared with him that she had researched her father but had stopped out of selfpreservation: "Sie habe mit ihren Nachforschungen aufhören müssen, weil irgendwann der Punkt erreicht war, an dem es ihr - als Tochter - zu nahe ging" (143). She claims that Uwe "als Enkel könne diesen Punkt überschreiten und weiter gehen" (143). Like Claudia 
Brunner, von Seltmann can only accomplish this with the help of a psychoanalyst familiar with the difficulties of dealing with the "NS-Problematik" (145).

Over time, von Seltmann gathered many details about his grandfather, and concludes his contribution to Schweigen die Täter, reden die Enkel with the comment that his grandfather's remains were never found. He apparently died when the Russian army invaded Neuhammer (Świętoszów, Poland) in February 1945. A grave is reportedly marked for his grandfather in the Vienna Central Cemetery, but he has never visited. He insists "Karlebachs Vermächtnis ist ein Roman und keine Autobiografie," but admits having to perhaps acknowledge "dass mein Buch doch mehr ist als ein Roman" (105).

The novel, with its corrupt characters still in power and a personal, heavy history for the protagonist to bear, certainly is proof of von Seltmann's opinion that: "Moralische Schuld vererbt sich nicht, aber die physischen, moralischen und sozialen Folgen ihres Beschweigens beschädigen noch die folgenden Generationen. Die Vergangenheit reicht in die Gegenwart hinein, wirkt in uns weiter, ob es uns passt oder nicht" (Brunner and von Seltmann 13). This third generation author has proven with his novel and his reflections that facing the past openly and honestly is the only way forward. 


\section{Chapter 3 - Die Dritten in Literature and Film \\ Winterkinder}

Throughout his documentary film, Winterkinder, which appeared in theaters in Germany in 2005, Jens Schanze leaves no doubt that his grandfather was a Nazi. In revealing how he pealed back the layers of history by availing himself of newspaper articles and official documents and reading letters written by his grandfather, Schanze questions only two things: the extent to which his mother's image of her father differs from the one he constructs, and what effect her lack of openness and honesty about the family history had on his and his sisters' upbringing. These epitomize the questions central to investigations of the third generation.

Claiming the idea for the project that would become Winterkinder had been on his and his sisters' minds for a time, Schanze read an article in 2002 that revealed something shocking: almost 50 percent of Germans questioned in a survey believed their relatives had been critical of National Socialism (Winterkinder, Extras). This told him that the questions he and his family were asking might have relevance to others. The documentary film was Schanze's final project at the School for Television and Film in Munich (Riepe).

Winterkinder features Jens' four sisters: Bärbel and Andrea, born in 1959; Kerstin, born in 1961; and, Annette, born in 1968. Jens was born in 1971. Each give quick introductions and reveal that they know next to nothing about their grandfather. He died in a car crash in 1954, before all of them were born, so none of them knew him personally. Bärbel admits she assumes he did what was necessary to make a decent life during the war; Andrea only recalls her mother describing him as "unser guter Vater;" 
Kerstin admits she feared him when she saw him in pictures and that she senses "schlimme Sachen" surrounded him; and Annette remembered he was her grandmother's great love, but knows nothing more. These vague descriptions pique interest right away. While the daughters describe what they know, images of a "typical," middle-class German family home fill the screen: things are tidy and well-tended, decorated for Christmas, furnished well but conservatively, the parents sit together and read the newspaper in companionable silence. Jens has asked his mother, on his and his sisters' behalf, for permission to create a documentary about her father and the family's memories of him; she has agreed. What unfolds is deeply personal. Antonie muses, after watching the documentary, whether others will understand, whether the documentary can have meaning for anyone else. For anyone willing to engage in the work this family has engaged in, the answer is a resounding yes. With its presentation, the filmmaker invites others to recognize themselves on the screen. A perfect example of the cultural production of the third generation, Winterkinder stands as testament to the generational differences in the approach to history and to the desire of the grandchildren to question and learn, end the silence and avoidance, and understand who they are and their place in the world.

Schanze is never hostile in asking his questions - he indicated in an interview about the making of the movie (Winterkinder, Extras), that he felt hostile confrontation would spoil his ability to accomplish his goals. It is clear from the way the family interacts, however, each feels deep respect for the other. The family is intact, and they are working on the project as a team. 
A snippet from Hitler in 1938 opens the documentary. With the backdrop of a landscape cold and bleak, the speech reminds the viewer that the regime claimed the youth of the country as its own:

'Und eine Jugend wächst da und die erziehen wir! Diese Jugend, die lernt ja nichts anderes als deutsch denken, deutsch handeln. Wenn nun dieser Knabe und dieses Mädchen mit ihren 10 Jahren in unsere Organisationen hineinkommen, dann kommen sie vier Jahre später vom Jungvolk in die Hitlerjugend, und dort behalten wir sie wieder 4 Jahre. Und sie werden nicht mehr frei ihr ganzes Leben!'

Two of these Winterkinder, Jens' Mutti, Antonie Schanze, born in 1933, and Papa, Horst Schanze, born in 1931, are subjects and participants of the documentary; and, one could argue, they were also subjects of Hitler's proclamation. They have lived under the heavy burden of the Hitler era their whole lives. While both have bright smiles and have clearly known prosperity and joy in their lives, their faces are also often grim, sad and guarded. They have agreed to the documentary, but the task is not a comfortable one for them.

Winterkinder is a movie about a family member who is never talked about. This point is made clear right away. Schanze asks Bärbel, one of the oldest twin daughters, if she can remember their mother ever relating a story from her childhood. Not only does Bärbel fairly bark the answer "Nee," she emphatically confirms that the past that was never discussed heavily influenced the atmosphere she grew up with and describes from memory as "nicht sehr warm und sehr still." She claims to know absolutely nothing about her grandfather. Andrea, the other twin daughter, reports that, from a very young age, she was afraid of family celebrations, because she knew they could "zum Eklat kommen" at 
any moment. She had heard from her mother's brother that he had been a bouncing baby who wore "Windeln mit dem Hakenkreuz drauf." She described always having known that, in her family, "war...ganz extrem was im Busch," but also understanding that her parents would never tell her anything. She resolved early on to approach her uncle at some point and get answers to her questions from him. The filmmaker makes clear that his knowledge of his grandfather at the start of the film is limited to a few personal items - binoculars and a pocket watch - his mother had given him, and a newspaper article with a few biographical details.

To further highlight the fact that the past had never been a topic of conversation, Schanze asks his parents if they ever talked with each other about their experiences during the war. The father speaks up and says he can recall at no time discussing anything and even claims he did not know his father-in-law "eben überhaupt doch in der Partei aktiv war." The viewer senses something cannot be right with this story - Antonie looks doubtful, but only very hesitantly says that her husband knew very much about her father. Letting her husband off the hook, however, she acknowledges that he probably knew more about the post-war era. Regardless, what is agreed upon between the two of them is that the war experiences were never a big topic. Antonie claims she would have told her husband anything, had he asked, especially because her husband knew her father and that would have made things easier than trying to explain things to her children who did not know him.

Antonie also claims to have never spoken with her own mother about her father. She felt that would not have been fair to do without him present: her mother was "untertan" to her husband and also "sehr begeistert" from all he accomplished. She had 
accepted things as they were, and Antonie describes her mother as having done no Auseinandersetzung about them.

Of course, what exactly the topics of any of these discussions would have been is not revealed for the viewer. All of the answers provided to the interviewer at this point in the documentary are very slow to come, seem very guarded, and are filled with silence and heaviness. These conversations are unpracticed; knowledge and information have never been shared.

More importantly than the silence within the family, though, is the avoidance with which Antonie has approached the topic for herself. It is clear that she has processed nothing about her father and his role in the war or the Hitler regime. Asked by her son with what emotions she reflects upon her father, her only answer is "Mit großer Liebe." Asked if anything has changed about that, especially in light of the work they are doing on the documentary together, she answers quickly, "Nein, da hat sich nichts verändert." Her tone indicates no reflection, and, in a provocative filmic technique, the camera pans to handmade childhood puppets, perhaps indicating the filmmaker views this as an answer frozen in a far off distant time.

Jens' father Horst also has skewed views of the past. In his opinion, just a few were really responsible for the Nazi atrocities: "Also, in meinen Augen, und ich glaube, das ist auch einigermaßen objektiv, mein Vater war nicht, ich denke, genauso wenig wie der Vater von der Mutti, aktiv in solche schrecklichen Verbrechen involviert. Ich denke mal, dass der Kreis derer, die da wirklich aktiv gewesen sind, relativ klein gewesen ist." To further highlight the point, Jens asks both his parents: "Und würdet ihr...Ich frage jetzt ja aus großer Distanz zu dieser Zeit, und eure Väter waren ja beide in der Partei...Würdet 
ihr sie als Nazis bezeichnen?" His father shakes his head "no" right away, but then answers: "Ja. Ich meine, formal natürlich ja. Klar. Aber..." and Antonie interrupts: "Aber Nazi finde ich nicht so schön, wenn man das sagt. Ich würde dann schon lieber Nationalsozialist sagen, also, wenn ich du wäre." The father keeps his eyes averted, answers nothing further, but continues to shake his head "no." What will be revealed through research is that Antonie's father was a high Party functionary to the bitter end. The question begs to be asked, if such a person was not a Nazi, then who was?

Harald Welzer reported hearing that participants in his study often viewed " 'die Nazis' auf der einen, die eigenen Familienmitglieder auf der anderen Seite" (Opa War kein Nazi 151). Made public in 2002 and commissioned by the Volkswagenstiftung, Welzer's study included multi-generational interviews with members of 40 families. Welzer wanted to know "was 'ganz normale' Deutsche aus der NS-Vergangenheit erinnern, wie sie darüber sprechen und was davon auf dem Wege kommunikativer Tradierung an die Kinder- und Enkelgenerationen weitergegeben wird" (11). While seeing the Nazis as the "other" might have been typical, Antonie's view really is quite extreme. The filmmaker does not ask what she sees as the difference between a "Nazi" and a "Nationalsozialist." Instead, he pans to a kitschy snow globe on the table. One imagines the filmmaker thinking: my parents have built themselves a bubble around an artificial world.

Antonie admits she had not wanted to discuss her father and his involvement with National Socialism in the past for several reasons: dealing with the topic was difficult; she was not clear on how to begin or on what was important; she felt it inappropriate to question his decisions; she found it unfair to portray him to people who never knew him. 
Schanze wonders why she has agreed to this "Auseinandersetzung" about him now, and Antonie answers "Eigentlich nur, weil ihr euch das gewünscht habt." The love she has for her children is evident in this remark. Antonie recognizes, in fairness to her children, the time has come to stop avoiding the topic.

The grown children indeed reveal that they have suffered under the weight of history. Andrea and Bärbel, the two oldest, appear to have dealt least well with the burden. Andrea suffered from nightmares as a youngster and wanted to talk about them with her father, who refused and treated her poorly for having asked. This was the experience that caused her to seek answers from her mother's brother, who seemed more willing. As an adult, he insisted to Andrea that his father had been an "intellektueller Täter," not a "Täter" in the sense of someone who had killed anyone. A dubious distinction when speaking about the Nazis in any case, Andrea suspected this might not be true, given how emphatically he repeated the phrase. Andrea concludes there is no way to explain his reaction other than to understand that no child can accept "seinen Vater als Mörder." While Andrea narrates, Antonie does chores in the background and the implication from the filmmaker is clear: this is not a truth Antonie would accept either. Andrea has an uneasy relationship with her mother, one built, up to this point at least, on an inability to ask and receive answers to important questions.

Bärbel is interviewed while she is ironing. The exchange can only be described as painful. Schanze gives his sister time for every measured answer she provides, but what is revealed is very little. She claims to not know her mother at all, sighs often, looks sad, and provides less than forthcoming answers. The interview ends with her putting her 
hands over her face in resignation. Bärbel clearly shows how difficult it is for her to reflect on her upbringing and her relationship with her mother.

In contrast to the two oldest siblings, Annette and Kerstin seem to have a closer relationship to their mother. While not free from the burden of the past, something was clearly different for them in their upbringing; what that might be is never discussed. Interviewed with her children running around her, Annette appears most well-adjusted of the daughters. Answering fully and with little prompting from her brother, Annette thinks their mother would not have ever spoken of her past if the children had not requested it. She attributes this to deep-seeded fears her mother holds - fear of what she will find if she looks too closely, fear of her children and their reaction, fear for her children and what the knowledge might do to them, fear that something will be broken in the process, fear that what she had successfully suppressed will come back up again. The filmmaker asks if Annette can claim she knows their parents, and she says she knows them from the heart. Given this answer, one believes she has analyzed the situation correctly. Annette is open and shows real affection for her mother, but she sees problems as well.

Kerstin relates a range of emotions and shows how deeply the process - working with her family on this documentary - has weighed on her mind. She has been dreaming she is in a group of people, and two people turn on others in the group and decide to kill them. What bothers Kerstin the most is that she found no way to stop them from doing so. She knew the actions were wrong and wanted to stop them, but did not succeed. Kerstin also speaks of at least two stories she had from her mother, stories of fleeing Neurode. Kerstin offers that this Lebensangst her mother suffered has surely been passed on to the children and admits that fear is a constant companion in her everyday life. She 
is plagued by questions such as "Wie kann ich überleben? Unter welchen Umständen kann ich überleben?" Very upset, she names the responsibility the family has to address this fear and attempt to conquer it. Her brother asks if she has ever approached this topic with her mother, and while she answers no, the viewer is left with the impression that this process will perhaps open that possibility for the future.

The past has clearly thrown shadows over Antonie's daughters. Interestingly, the filmmaker does not ask them what they are feeling, and they do not speak of feeling guilt, extreme sadness or remorse. The viewer is left to speculate on how they would describe the burden; it is, however, undeniable.

The rest of the documentary is a confrontation with details about Schanze's grandfather. They leave no doubt about his activities during the war, but Schanze also acknowledges that no individual is one-sided. He was a father, and Antonie remembers that he was a gifted Kasperlepuppenspieler and that he would play with his children when he had time. Schanze's difficult task is to somehow unite the disparate aspects of his grandfather's life, not only for himself, but for his mother as well.

Harald Welzer addressed the complexity of this task in his report on the study Opa war kein Nazi. Not surprisingly, Welzer described that German families have two sources of information about the past: an Album of emotion-based information, and a Lexikon of knowledge-based information (10). Welzer claims that he often saw the emotion-based information led study participants to have impressions of "Heldentum, Leiden, Verzicht und Opferschaft" in their families, while the knowledge-based information focused on "Verbrechen, Ausgrenzung und Vernichtung" (10). Schanze has access to both types of information about his grandfather. 
Welzer also described how Raul Hilberg, the well-known Holocaust scholar who died in 2007, called the Holocaust in Germany "Familiengschichte" (Opa war kein Nazi 10), and that families have a responsibility to merge Album and Lexikon information. Welzer goes on to say: "Ein Medium für diese Verfertigung der Vergangenheit (neben vielen anderen) ist das familiale Gespräch, in dem en passant Geschichtsbilder entworfen und gesichert werden, mit denen alle Familienmitglieder leben können" (10). While Welzer concludes that "living with" the images of history for his study participants often meant concluding "Opa war kein Nazi", that is not the conclusion Schanze presents of his grandfather. The documentary can be seen, however, as the requisite "familiale Gespräch" Welzer describes.

In his first sleuthing act, Schanze advertised in what he terms "meiner Heimatszeitung", asking for information from anyone who might have known his grandfather. A woman, Edith Herden, answers in a letter Schanze shares with his mother. Antonie wishes to process the letter off-camera, and in keeping with the tone throughout the documentary, Schanze allows her space to do this. Antonie is shown in another room, reading the letter.

When she is ready to discuss the contents of the letter with her son, Antonie perplexingly admits to not remembering Edith as well as she claims to remember Antonie. Edith writes that the two were best friends; Antonie hesitates and says, "Ja, ich muss da viel drüber nachdenken. Aber sie wird schon Recht haben." The viewer wonders where the discrepancy lies - is Edith claiming a relationship that does not exist or has Antonie forgotten so completely? The answer is never specifically provided, although when the two women meet, they reflect on a childhood together that was "wunderbar" 
and the scene is emotional. They pour over picture albums and reflect on hours spent together, playing games, riding bikes, and jumping around the family home, which they were allowed to do only at Antonie's. Edith says that she views Antonie as a sister, given how much time they spent together and how close they were.

Not allowing the true topic to get lost in the shuffle, the filmmaker asks what Edith specifically remembers about his grandfather. Edith says "Ich habe nur gute Erinnerungen...bei Schülkes dürften wir alles...wir waren lebhafte Kinder in dem Haus." With these snippets, Schanze fills in some details about his mother's childhood.

Antonie ironically comments: "Ja. Das ist natürlich eine kluge Frage von ihr, warum du dich an Fremde wendest, wenn du was von deinem Großvater wissen willst." In addition, Antonie reflects on why, when Edith remembers so much, she remembers so little. Answering her own questions, however, she says: "Aber ich hab es wahrscheinlich auch immer verdrängt, weil das so schrecklich war, da bei Nacht und Nebel ohne Abschied wegzumüssen. Ich hab ja auch meine ganze Jugendzeit darunter gelitten. Ich hatte immer Heimweh, aber wahrscheinlich wollte ich mir das auch alles gar nicht vorstellen."

A fairly insightful answer, neither she nor Edith see any irony when, in the very next snippet, both claim to know "nichts weiter" about "Nationalsozialismus." Jens interrupts this conversation to remind them that they had mentioned the concentration camp Groß-Rosen. Edith staunchly insists she does not know of that, but muses through what she does know, mentioning the towns of Donnerau and Wüstegiersdorf. She locates her knowledge very specifically to the more than 100 camps that belonged to the complex Groß-Rosen. Edith admits to memories of walking with her grandmother and seeing 
prisoners in striped uniforms, whom her grandmother identified as "eingesperrte Juden." The grandmother quickly scooted the girl away. With this scene, Schanze focuses on the complexities of untangling memory, of seeking what has been suppressed, and highlights the difference between not knowing and not wanting to know. Antonie admits to suppressing bad memories, and Edith admits to information she only somewhat wants to acknowledge.

Fortunate to have access to words directly from his grandfather, in that he has been allowed to read letters his grandfather wrote to his mother from Neurode starting when the family moved there in 1937 , the filmmaker shares several with the viewer over the course of the movie. Strategically placed to slowly reveal exactly how the grandfather spent his time, the letters leave no doubt as to his disposition.

The first letter, from October 10,1939, describes how busy he is and why: besides his normal work as an engineer in the coalmine in Neurode, he is otherwise "sehr viel in der Partei." He speaks publicly twice a week and works at a Party daily, the Grenzwacht, at least once a week. He has saved all newspapers from September 1st on (the German invasion of Poland) and states his goal: "diesen Krieg durchhalten." To that end, he took on the position of "Stadtrat im Neuroder Gemeinderat für einen ausscheidenden Obersturmführer der SA" and explains to his mother "Ihr seht also, dass ich mich auch als Heimatkrieger tüchtig einsetze." The grandfather's own words, at minimum, reveal him to be an active supporter of the war effort.

This attitude continues. As late as Christmas 1944, he writes he hopes the coming year will bring "den ersehnten, siegreichen Frieden;" and, in February 1945, he comments that the men are holding fast, will stay and continue to fight. The war can only 
be won, he writes, if everyone stays brave, and the war has to be won, "sonst ist alles verloren." He urges his mother to stay healthy and to help win the war.

In March 1945, Schülke was thrown out of the party. He was not allowed to speak at a holiday event and describes the experience as "schmerzlich" and an order that he would contest. In other words, he still very much wanted to be a Party member as late as March 1945. He was thrown out, because he got his wife and children out of Neurode in advance of the evacuation orders and thereby tarnished the party's image. Only at this time does he write of doubts, regrets or disillusionment, and these must be seen in light of the fact that the writing really was on the wall at this point. He awaits the "vom Führer angekündigte, ja sogar prophezeite siegreiche Wende dieses Krieges" and experiences "Unsicherheit, ja Vertrauenskrise und teilweise Resignation." Written by a true believer, these letters provide invaluable information about the grandfather's disposition, and in their authenticity, serve as a source of Lexikon information for the family.

Because his grandfather worked for a daily newspaper, pubic evidence of his work is also available. Schanze researches the daily newspaper, the Grenzwacht, in the Staatsbibliothek München. Armed with information from this newspaper - an article he found from June 30, 1940 - Schanze portrays, in sharp clarity, the difference between what his grandfather revealed of himself and what his daughter will admit about him. The Grenzwacht reports that:

Der Ortsschulungsleiter, Parteigenosse Schülke, kam in weit reichenden geschichtlichen Ausführungen auf das Thema England und die Juden. Parteigenosse Schülke betonte, dass sich die Engländer aufgrund einer alten Sage als ein Stamm Israels und als auserwähltes Volk fühlten. Er 
schilderte, wie die Juden es mit der Zeit verstanden hätten, in die höchsten englischen Staatsämter einzudringen, um England zu einer Hochburg des jüdischen Weltmachtstrebens zu machen. Das scharfe Schwert der deutschen Wehrmacht würde dafür sorgen, dass in nächster Zeit diese Geißeln der ganzen Menschheit verschwänden. Mit einem Ausblick auf die Unzerstörbarkeit des neuen Deutschlands schloss Parteigenosse Schülke seine Rede.

In the NS-Archiv der DDR, in Dahlwitz-Hoppegarten, Schanze finds his grandfather's speaker identification card. Schanze poses a question to his mother to which the audience is not privy, but her answer illustrates the nature of the conversation: Antonie tells her son: "Das ist ganz schwierig. Das kann natürlich auch sein, dass ich für mich persönlich annehmen möchte, dass für ihn ein Jude genauso ein Mensch war wie jeder andere. Aber das sind eben meine Wünsche, die ich gerne verwirklicht haben möchte, aber das geht ja nicht mehr..." Antonie claims to want to believe something that is really not possible in the face of hard evidence, but then she also admits that she knows her father belonged to a student organization that had been formed to make sure the number of Jewish professors at the university did not get "überhand." She relays this information with closed eyes; only when she finishes her sentence does she look at her son. It is clear Antonie knows her father held deeply anti-Semitic views, but with her actions she shows she does not want to accept this fact.

The student organization the grandfather belonged to - the viewer sees his picture on the wall of the meetinghouse - was the Verein Deutscher Studenten in Freiberg, Saxony. Schanze visited and confirmed, by talking to current members, that the group at 
the time was nationalistic, politically active and anti-Semitic. Schanze confirmed his mother's suspicions for the viewer.

Standing on the grounds of the concentration camp Groß-Rosen, Antonie must confront another uncomfortable realization about her parents. Jens reminds Antonie that she had visited the concentration camp at Groß-Rosen once before. After that visit, she wrote to her son that she would have liked to have spoken with her parents. Jens asks her why, indicating that had not been asked before. Crying, and with a very heavy sigh that seems to indicate resignation, Antonie answers: "Ja, weil ich gerne wissen wollte, ob sie das gewusst haben, dass hier so ein Lager war." She refuses to speculate on the answer, but admits again that she would like to believe that they did not know. This remains an unfulfilled desire, as Jens reads from a letter Antonie's mother wrote to her sister in February 1944, stating "Vor allem haben sie da ein Lager in der Nähe mit 30.000 Juden und sie meinten, wenn da mal Bomben reinfielen und die Juden frei würden, wär's fürchterlich." The filmmaker does not share his mother's reaction upon being confronted with the knowledge that her parents certainly did know of the concentration camp.

Through this process of looking at the past, Antonie had to acknowledge truths about her father that she had not ever acknowledged before. Jens asks her, at two different points in the movie, if her opinion of him had changed. In the beginning of the movie, the answer is no, although in the emphatic way she answers, the viewer wonders if she is not trying to convince herself of this truth. She does not look her son in the eye and she offers no further comment. By the end of the movie, having visited her "Heimatstadt" and processed much information, her answer is "...es hat meiner Liebe zu ihm keinen Abbruch getan. Und es bleiben eben ganz viele Fragen offen." With these 
words, and especially with the word "und," Antonie has summarized the modern approach to die Auseinandersetzung mit der Vergangenheit: she holds good memories of her father and recognizes there are impactful pieces of information that have to inform that simple picture, as well as many things that can never be justified.

To close the documentary, the family stands for one last family photo, a nod to all the pictures that have been shown throughout and in commemoration of the process they have gone through together. No one abandoned the project; everyone is able to join in a viewing of the film. Annette comments that she thinks her mother seems relieved relieved to have had the opportunity to do this Auseinandersetzung. In family discussion, however, the heaviness of the information is not forgotten. Antonie claims "Ich hab ja Doppeltes zu verkraften. Ich hab nicht nur das zu verkraften, was ihr sagt, und das sind ja schon Klöpse, und alles andere. Und dann bin ich gespannt, was meine Brüder sagen. Aber ich hab es ja nun...Ich hab nun "ja" gesagt." Kerstin tells her mother she is happy to have had the opportunity to get to know her mother better, that a closeness developed she knows to appreciate, and that the process was satisfying. Antonie agrees.

In recognition of the importance of merging family stories with historical facts to assemble a complete picture, the documentary closes with the whole family - the fourth generation included - visiting and discussing the concentration camp and the Heimatstadt Neurode. By including this scene, the filmmaker reminds the viewer that the documentary is not an end in and of itself. To have succeeded in its goals, Winterkinder would be viewed as a roadmap for an ongoing process others would go through, in service of openness and honesty. As is certainly true for the Schanze family, the filmmaker is saying, die Enkel can flourish with nothing less. 


\section{Conclusion}

The enormity of the Holocaust has been tackled in cultural production through the decades. Early social critics, like Theodor Adorno, worried that such a difficult past would be avoided as soon as possible. Not only did he think that those who deserve to be remembered would not be with such avoidance, Adorno believed that a healthy society would not emerge without keen individual account-taking. Adorno wrote with the sensibility of the time: the confrontation would be something to engage in and then move on from, a process to be accomplished. The current generation, named die Dritten or die Enkel, has answered Adorno's worries by continuing to take up the topic of the past and its ramifications, even more than sixty years on, and making clear that there are still issues that matter very much to current society. These authors investigate from their perspective and, given the distance to the issues, approach the topic with keen desire to know and to understand, and with less accusation than their fathers and mothers. They are proving themselves willing and capable of producing works that are appealing and true to the process of confrontation.

Cultural production reflects the state of society on matters of the day. Ernestine Schlant took a broad view in her analysis of efforts by authors to represent the Holocaust in literature from the end of the war until re-unification in 1989; she found their efforts, described as "presence through absence," wanting on several fronts. While some of the inadequacies have arguably been addressed by authors of the modern generation, most striking is the current attitude that the Holocaust remains relevant and is not something to be "worked through" in order to be "moved on from." 
Schlant was most critical of authors who showed no ability to mourn all that had been destroyed and no willingness to present individuals as victims of the murderous regime. While these are not unreasonable demands on those professing to process information on behalf of others, which authors certainly do, one must acknowledge that the enormity of the Holocaust is nothing if not challenging to process. The ground fertile enough for such insanity could not be eradicated overnight, or via Entnazifizierung, or even after two or three decades. Given that literature and other art reflect society and must be viewed in continuity, Schlant's criticism of the cultural production in the first post-war decades reflects criticism of a society that had yet to accept its responsibility for the Nazi era. Given the aspirations of West Germany to be a democracy of social and liberal ideals, much work remained.

Austrian author Claudia Brunner recognized as much while processing her infamous relative's contributions to the Nazi machine. Acknowledging that her story had a private as well as a public element, Brunner spoke of what has now been accepted as a given, that a country's history is family history when it comes to the Holocaust. What her memoir reveals, however, is how successfully the past could be avoided if so desired. Even with Alois Brunner as a relative, the past had never been discussed in her family until she voluntarily took up the topic. Like others, Claudia sensed something was amiss with this relative, but the lack of words from the first and second generations gave clear indication that the topic was off limits. How a whole society could live with such silence and avoidance is reflected in her musings about how an old president of her country, Kurt Waldheim, claimed lack of knowledge about certain events during the war and yet had been elected president. In other words, living with Nazi skeletons in the closet happened 
on all levels of society, even to relatively successful politicians. But in this public story and in her private story lies the truth that what had been acceptable before is no longer. The silence of the earlier generations is being confronted, and the third generation will speak. Brunner reflected this attitude in the title of her book, Schweigen die Täter, reden die Enkel.

The weight of what Brunner learned about her relative and her country through her research, however, took its toll on her. Not only did she write of seeking professional help to deal with the burden, Brunner described an inner tension between the desire to know as much as possible and the desire to stay away out of self-preservation. Given that a confrontation with the past will never bring closure, especially when the confrontation is with people one will never see, it is understandable that one would go back and forth between these two emotions. Brunner's contribution is to acknowledge that the confrontation has to be done, however, and that the pain it causes in those who take it on is not to be underestimated or written off as unreal. Brunner found resonance from others when describing how difficult it was for her to live with knowledge of the past, but through her memoir makes clear that the silence and avoidance of the past must be things of the past.

Dückers' most significant contribution to the third generation response is how she portrays a completely normal family's connection to the National Socialist era. The main character in Himmelskörper, Freia, has no special, high-level Nazi relative hidden in the closet. The family is upper middle class, thereby not looking like a large portion of German society to be sure, but they clearly represent the everyman in many ways especially in how Freia and her brother are educated in school about the Holocaust. 
Dückers makes clear that, where school leaves off, with its repeated curriculum and simple, dry running through of the era as if it were simply any other era in history, family history begins.

The secret Freia is compelled to uncover and process is that her grandparents were run-of-the-mill, everyday Nazis. Freia's grandmother often portrayed their connection to the Party as vaguely as possible, or would pick and choose policies to distance herself to in retrospect, or even go so far as to say they were not Nazis. Freia is suspect from an early age; she is confused, for example, about how the BDM-Zeit could be the best of her grandmother's life. The family secret that no one addresses head-on and that Freia has to uncover bit by bit, the last chapter of which only happens while cleaning out her grandparents' home after their death, is that her grandparents were active supporters of the Nazis. They had not renounced these beliefs, as attested to by the fact that Hitler's book remained a treasured, if hidden, possession. Freia's grandparents were some of the millions who made the Nazi machinery go round. Dückers provides no grim details - Jo and Mäxchen did not work in a concentration camp or take part in any highlevel war plans. They were members of the masses and, but for the defeat of their country, evidently saw no problem with the beliefs they held and had been passing on to their daughter. Her task in moving forward is to reconcile her memories with the knowledge she now has, the weight of which causes her mother to commit suicide. With this take on the processing of history, Dückers is making clear that normal, everyday people in German society cannot escape a reckoning with the past. While surely not everyone will have to face such dramatic details in their family history, owning the past is 
a responsibility that normal people have. The questions have to be asked, the answers sought and internalized.

Dückers writes of a granddaughter who tackles this confrontation. With her work, she portrays the unique ability and viewpoint of members of the third generation: they seek answers with a distance to the time that, in contrast to the second generation, does not look like attack or judgment; they have a unique responsibility to try to get the last bit of information they can from those who lived during the time before they have all passed; and, they need to reconcile the dry, official information they receive through education with their own family history. Dückers' Freia does this; audience members will see themselves reflected in the character.

Uwe von Seltmann's novel, Karlebachs Vermächtnis, is the least sophisticated of the works explored. Given the overall lightheartedness of the story and the fact that the main character is an immature student trying to make his way, the novel clearly could, however, successfully reach its intended audience and is therefore valuable in its contribution.

The oldest of the authors whose works were explored, von Seltmann released his novel earliest. As such, his narrative represents an early attempt of the third generation. Because he covers so many topics, each is only superficially addressed: the second generation is treated either accusatorially or as innocent bystanders with no stake in the history, like Ulrich's father who should engage in the history of his own father but is never shown doing so; Nazi atrocities are presented almost as a freak side attraction for a reader who is completely uneducated on the topic; the Jewish protagonist has to be sought out in Israel with complicated cultural prejudices presented as cliché; the burden 
of dealing with a Nazi grandfather is simplistically abandoned, because the Jewish victim offers his absolution; and, the main character can only solve his problems by abandoning his society out of disappointment in their lack of ability to hold criminals to account. Very much the stuff of fiction, the plot entertains and provokes thought about unpunished crimes and criminals who survived and thrived into modern day, but the breadth of topics distracts the reader and lacks the focus of the other works examined.

Schanze's documentary film, Winterkinder, engages the audience completely differently than the other works. In watching real people answer questions that are clearly very sensitive, the audience connects on an emotional level. With deep respect for his mother, Antonie, Schanze creates a film that is a successful representation of the viewpoints of the third generation: truths about a family member have been avoided and denied, and for the sake of all concerned, that pattern must end.

One wonders how Antonie, a member of the second generation, avoided previous confrontation with the past. Her father had been a high-level Party functionary to the bitter end and had escaped any post-war prosecution. He had, however, died in the 1950s, during a decade when confrontation with the past was on no one's agenda and at roughly the time of Adorno's musings about the need for this confrontation. Antonie was also an older member of the second generation - she was a 35-year-old mother of four when the 68ers were most active. Antonie reflects the continuity of society's confrontation on the topic of the Holocaust, and her story, as represented in her son's documentary, proves a central tenet of this investigation: the third generation recognizes how damaging silence and avoidance have been and sees no way forward other than to own up to the knowledge and to help others do so, as difficult as it may be to accept. 
All the works examined feature members of the third generation who have to know the legacy of the past as reflected in their family history. They can get at this knowledge more successfully than previous generations, given the distance to the past and their desire to keep relationships intact. Die Dritten do this work in hopes that others will, too, and as a reflection of current attitudes that represent a hope for a healthier and more enlightened future. As these authors have concluded, this is not work that will have an endpoint. Perhaps assuming that an end to the Auseindersetzung could have been achieved only through the passage of time was the error they have corrected with their work. 


\section{Sources Cited}

Adorno, Theodor W. Critical Models: Interventions and Catchwords. New York: Columbia UP, 1998. Print.

Adorno, Theodor W. Eingriffe. Neun Kritische Modelle. 8. ed. Frankfurt Am Main: Suhrkamp, 1974. Print.

Biendarra, Anke S. Germans Going Global: Contemporary Literature and Cultural Globalization. Berlin; Boston: De Gruyter, 2012. Print.

Brockmann, Stephen. Revisiting Zero Hour 1945: The Emergence of Postwar German Culture. Washington, D.C.: AICGS, 1996. Print.

Brunner, Claudia, and Uwe von Seltmann. Schweigen die Täter, reden die Enkel. Frankfurt am Main: Edition Büchergilde, 2004. Print.

"Der nüchterne Blick der Enkel" Die Zeit 30 April 2003. Web. Last accessed: 17 Nov. 2014. <http://www.tanjadueckers.de/rubrik/gespraeche/>.

"Der Schrecken nimmt nicht ab, sondern wächst" Süddeutsche Zeitung 27-28 April 2002. Web. Last accessed: 17 Nov. 2014.<http://www.tanjadueckers.de/rubrik/politik/>.

Dückers, Tanja. Himmelskörper : Roman. 2.nd ed. Berlin: Aufbau-Verlag, 2005. Print. Fagan, Andrew. Theodor Adorno (1903-1969). Internet Encyclopedia of Philosophy. Web. Last accessed: 17 Nov. 2014. <http://www.iep.utm.edu/adorno/>.

Ganeva, Mila. "From West-German Väterliteratur to Post-Wall Enkelliteratur: The End of the Generation Conflict in Marcel Beyer's Spione and Tanja Dückers's Himmelskörper." Seminar: A Journal of Germanic Studies 2 (2007): 149-62. Print. 
Garscha, Winfried R. Holocaust vor Gericht: Die Deportation der Wiener Juden in den Jahren 1941 und 1942 und die österreichische Justiz nach 1945. Web. Last accessed 17 Nov. 2014. $<$ http://www.nachkriegsjustiz.at/ns_verbrechen/juden/deport_wien_wrg.php>.

Riepe, Adele. Winterkinder - die schweigende Generation. Web. Last accessed: 17 Nov. 2014. < http://www.kinocritics.com/film_review.php?f=156>.

Schlant, E. (1999). The Language of Silence: West German Literature and the Holocaust. New York: Routledge.

Schneider, Peter. "Hitler's Shadow; on Being a Self-conscious German. (Today's Germany and Hitler's Legacy)." Harper's Magazine (1987): 49. Print. "Sehen, suchen, schreiben" Mitteldeutsche Zeitung 12 Juni 2003. Web. Last accessed: 17 Nov. 2014. <http://www.tanjadueckers.de/rubrik/gespraeche/>.

Seltmann, Uwe . Karlebachs Vermächtnis: Roman. Gerlingen: Bleicher, 2000. Print Uwe von Seltmann. Web. Last accessed: 17 Nov. 2014. $<$ http://uwevonseltmann.wordpress.com/biografie/>. Welzer, Harald. Grandpa Wasn't a Nazi: The Holocaust in German Family Remembrance. New York: American Jewish Committee, 2005. Print.

Welzer, Harald. Opa War Kein Nazi: Nationalsozialismus und Holocaust im Familiengedächtnis. 4. th ed. Frankfurt Am Main: Fischer Taschenbuch, 2002. Print.

Winterkinder - die schweigende Generation. Dir. Jens Schanze. Tiberius Film, 2005. Film. 
Zuroff, Efraim. Simon Wiesenthal Center 2013 Annual Report on the Status of Nazi War Criminals. Web. Last accessed: 17. Nov. 2014. http://www.wiesenthal.com/atf/cf/\%7B54d385e6-flb9-4e9f-8e94890c3e6dd277\%7D/NAZI-WAR-CRIMINALS-REPORT_2013.PDF. 